Discussion Paper No. 14-009

If You Don't Succeed, Should You Try Again?

The Role of Entrepreneurial Experience in Venture Survival

Sandra Gottschalk, Francis J. Greene,

Daniel Höwer, and Bettina Müller

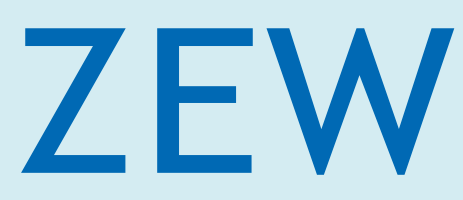

Zentrum für Europäische Wirtschaftsforschung $\mathrm{GmbH}$

Centre for European

Economic Research 


\title{
Discussion Paper No. 14-009 \\ If You Don't Succeed, Should You Try Again? The Role of Entrepreneurial Experience in Venture Survival
}

\author{
Sandra Gottschalk, Francis J. Greene, \\ Daniel Höwer, and Bettina Müller
}

Download this ZEW Discussion Paper from our ftp server:

http://ftp.zew.de/pub/zew-docs/dp/dp14009.pdf

Die Discussion Papers dienen einer möglichst schnellen Verbreitung von neueren Forschungsarbeiten des ZEW. Die Beiträge liegen in alleiniger Verantwortung der Autoren und stellen nicht notwendigerweise die Meinung des ZEW dar.

Discussion Papers are intended to make results of ZEW research promptly available to other economists in order to encourage discussion and suggestions for revisions. The authors are solely responsible for the contents which do not necessarily represent the opinion of the ZEW. 


\title{
If you don't succeed, should you try again? The role of entrepreneurial experience in venture survival
}

Sandra Gottschalk*, Francis J. Greene**, Daniel Höwer***, and Bettina Müller****

\begin{abstract}
There remains considerable scholarly debate about the role that prior entrepreneurial experience plays in new venture survival. Drawing on entrepreneurial learning theories, we use panel data on 8,400 new ventures to investigate the impact of four different types of prior entrepreneurial experience (portfolio, serial, failure (bankruptcy/voluntary dissolution) and a mix of success (portfolio/serial) and failure (prior bankruptcy/dissolution) on venture survival outcomes. We find that previously failed entrepreneurs are less likely to survive and, in common with entrepreneurs with mixed prior experiences, are more likely to experience bankruptcy. We find that portfolio and serial experience is unrelated to survival or avoiding bankruptcy. Conclusions for entrepreneurship scholars, entrepreneurs and stakeholders are discussed.
\end{abstract}

Keywords: venture survival, entrepreneurial experience, panel data

JEL classification: $L 26$, L25

\section{Acknowledgements}

We would like to thank the following people for their helpful comments in the developing this paper: Alex Coad, Paolo Di Martino, Michaela Niefert, Konrad Stahl, David Storey and Deniz Ucsbasaran. The usual disclaimer applies.

In this study we use two datasets: First: The KfW/ZEW Start-up Panel (www.gruendungspanel.de) is co-funded by the KfW Banking group (www.kfw.de) the ZEW and Creditreform (www.creditreform.de). Second: The Mannheim Enterprise Panel contains firm credit rating information collected by Creditreform. Data usage is only possible due to the long-term collaboration between Creditreform and ZEW. We acknowledge ongoing technical support by Creditreform.

An overview of our projects can be viewed on the following websites:

http://www.zew.de/de/mitarbeiter/mitarbeiter.php3?action=mita\&kurz=sgo

http://www.zew.de/de/mitarbeiter/mitarbeiter.php3?action=mita\&kurz=dho http://www.zew.de/de/mitarbeiter/mitarbeiter.php3?action=mita\&kurz=bmu

* $\quad$ Centre for European Economic Research (ZEW), Research Department Industrial Economics and International Management, P.O. Box 103443, D-68034 Mannheim, Gottschalk@zew.de .

** University of Birmingham, Edgbaston, Department of Management, B15 2TT, UK,

f.greene@bham.ac.uk +44 (0) 1214143277.

*** LBBW, P.O. Box 106049, D-70173 Stuttgart, l.hoewer@lbbw.de.

**** Centre for European Economic Research (ZEW), Research Department Industrial Economics and International Management, P.O. Box 103443, D-68034 Mannheim, Bettina.mueller@zew.de. 


\section{Introduction}

A growing body of literature has addressed the role that prior entrepreneurial experience plays in influencing subsequent entrepreneurial performance (Stuart and Abetti, 1990; Westhead and Wright, 1998; Ucbasaran, Westhead and Wright, 2006). The basic assumption is that those entrepreneurs with prior entrepreneurial experience are more likely to have positive entrepreneurial outcomes (Cope, 2011; Minniti and Bygrave, 2001) than novice entrepreneurs (individuals with no prior business founding experience and who currently own a business) (Ucbasaran, Westhead, Wright and Flores, 2010). Recent evidence has also begun to emerge which suggests that the outcomes of prior entrepreneurial experience is important in explaining the subsequent entrepreneurial endeavors of entrepreneurs. Gompers, Lerner, Scharfstein and Kovner (2010) - albeit just for venture capital backed firms - show that previously successful entrepreneurs are more likely to be successful than novice entrepreneurs in their new focal venture. This is because previously successful entrepreneurs are more likely to attract external funding and use their prior experience to develop a successful market entry strategy. In other words, Gompers et al (2010) argue that success breeds success.

What, however, is less clear is if failure breeds success. If entrepreneurs experience failure, should they try again? Entrepreneurial learning theorists suggest that failure experience has a profound and positive impact on subsequent venture performance (Cope, 2011). Corbett (2005, 2007) argues that entrepreneurs learn through experience and improvisation, suggesting that prior failure experience prompts the development of experiential heuristics which can be beneficial to the sustainability of new ventures. Smilor (1997) states that entrepreneurs “learn from what works and, more importantly, from what doesn't work” (p.344) and further studies identify that business owners credit their future success to prior failures (Cardon and McGrath, 1999; Minniti and Bygrave, 2001; Sitkin, 1992). Nonetheless, findings such as these are typically based on small-scale qualitative studies. Quantitative evidence contradicts the assertion that failure leads to subsequent venture survival (Frankish, 
Roberts, Coad, Spears and Storey, 2012; Neilsen and Sarasvathy, 2011; Ucbasaran et al, 2006).

The aim of this paper is to investigate the impact of prior entrepreneurial experience on venture survival outcomes. For the first time - as far as we are aware - we examine four types of prior entrepreneurial experience. The first two we consider as 'successful' prior entrepreneurial experience: portfolio (here defined as entrepreneurs concurrently running at least one venture besides the focal venture) and serial entrepreneurs (defined as entrepreneurs that prior to the focal venture ran a venture and either sold their business or passed it on to a successor). We distinguish between these two types of successful entrepreneurial experience because we conjecture that there are discernible survival differences between these two groups. We argue that, relative to novice entrepreneurs, portfolio entrepreneurs are more likely to have better survival outcomes than serial entrepreneurs, because they have greater levels of 'content domain' experience (Toft-Kehler, Wennberg and Kim, 2013). Our third group is those that have 'failed' in a prior venture. We define these as entrepreneurs that prior to the focal venture ran a venture that went bankrupt or was voluntarily dissolved. We argue that these are more likely to have positive survival outcomes than novice entrepreneurs because of they derive learning benefits from their prior experience of failure. Finally, based upon the above definitions, we examine entrepreneurs with a 'mixed' experience of both 'success' and 'failure', again arguing that these entrepreneurs are more likely to survive than novice entrepreneurs. Our aim in distinguishing these four types of entrepreneurial experience is to respond to calls (Ucsbasaran, Shepherd, Lockett and Lyon, 2012; Neilsen and Sarasvathy, 2011) for a more nuanced approach to different forms of entrepreneurial experience.

We examine two types of venture survival outcome. First, we consider if the focal venture survives. Second, we disaggregate this standard binary approach by considering if the non-surviving focal venture is either voluntarily dissolved or goes bankrupt. We focus on these outcomes because prior research has identified the need for a richer conceptualization of 
exit events (Wennberg and DeTienne, forthcoming; Coad, 2013; Wennberg, Wiklund, DeTienne, \& Cardon, 2010). We examine voluntary dissolution because it has been used to better understand how entrepreneurs realize that the venture has fallen short of the goals they set for their venture (Gimeno, Folta, Cooper and Woo, 1997; McGrath, 1999; Ucbasaran et al, 2013). We also focus on bankruptcy because it is an unambiguous indication of poor economic performance (Carter and van Auken, 2006). In overall terms, we ask two central research questions. First, do these different forms of entrepreneurial experience impact on the survival of the new focal venture? Second, what impact do these different forms of entrepreneurial experience have on the likelihood of voluntary dissolution or bankruptcy in the new focal venture?

These are important research questions for three reasons. First, relative to our understanding of start-up or growth, venture failure generally remains an under-researched area (Blackburn and Kovalainen, 2009; DeTienne, 2010; Wennberg et al, 2010). This is despite failure being a common outcome for new and small ventures (Knaup and Piazza, 2007).

Second, for researchers interested in entrepreneurial learning there remain open questions about the pathways by which prior entrepreneurial experience influences subsequent venture survival. In specific, some researchers identify that entrepreneurial experience is a valuable form of experiential learning that can be potentially successfully transferred to a new venture (Politis, 2005; Shepherd, 2003; Autio and Pathak, 2010). In contrast, a range of studies have identified reasons why experience may be a poor guide to future venture survival. Frankish et al (2012) argue that, because uncertainty is endemic in entrepreneurial settings no two business situations are identical, implying that experience has limited efficacy for the entrepreneur in their new focal venture. Learning theorists (e.g. Kahneman et al, 1982; March 2010) also identify that transferring knowledge gained from prior experiences is difficult in complex situations and that generalizing from past experiences can lead to unfavorable outcomes (Mazur, 1994). Entrepreneurs are also prone to over-optimism (De Meza, 2002; Fraser 
and Greene, 2006) and often attribute failure to others rather than themselves (Diwas, Staats, and Gino, 2013). Parker (2006) shows further entrepreneurs typically make few adjustments to their behaviour in the face of prior evidence whilst Eesley and Roberts (2012) Chen (2013), Rocha, Carneiro and Varum (2013) all argue that entrepreneurial talent rather than entrepreneurial experience is more likely to determine venture outcomes. Overall, there is a need for research to explore if, indeed, prior entrepreneurial experience is efficacious, particularly to support the formation of guidance to entrepreneurs.

Finally, although the positive evidence on the efficacy of prior entrepreneurial failure as a precursor to entrepreneurial success remains limited (Ucbasaran et al, 2013), Lee, Peng and Barney (2007) and Lee, Yamakawa, Peng and Barney (2011) have advocated the relaxation of bankruptcy laws. Policy makers have also adopted policies to relax bankruptcy laws in the belief that failure breeds success. For example, the European Commission (2003) state that "failed entrepreneurs learn from their mistakes and perform better in their next business" (p.22). This is despite as Ucbasaran et al (2013) indicate that "unfortunately, there is an absence of research testing this proposition, which is not surprising given the need for a large longitudinal panel database containing a large number of entrepreneurs” (p. 187). Testing the value of different forms of entrepreneurial experience on venture survival outcomes can potentially guide policy makers, practitioners and scholars in this important area.

Our empirical approach is to use the longitudinal KfW/ZEW Start-Up Panel data on 8,400 new German ventures founded between 2005 and 2011 and to estimate two duration models (survival time and competing risks) that determine the relationship between prior entrepreneurial experience and the survival outcomes of the focal venture. In the next section, we develop our hypotheses. Section 3 delineates our panel data and our survival time models. In Section 4 we present our results before Section 5 concludes with a discussion of our findings and the implications they have for entrepreneurship scholars, entrepreneurs and stakeholders. 


\section{Hypotheses}

In this section, we develop hypotheses consistent with theories of entrepreneurial learning that argue that all types of prior entrepreneurial experience leads to better venture survival outcomes. While doing this, we recognize that the efficacy of prior entrepreneurial experience to venture survival outcomes is yet to be shown (Ucbasaran et al, 2013), and that entrepreneurial experience brings both assets and liabilities (Ucbasaran et al, 2006).

\subsection{Prior entrepreneurial success experience}

Entrepreneurial learning theorists argue that prior entrepreneurial success potentially provides a number of assets to entrepreneurs in their new focal venture. Central to entrepreneurial processes is the identification and exploitation of business opportunities (Shane and Venkataraman, 2000). For both portfolio and serial entrepreneurs, experience may furnish entrepreneurs with the ability to better foresee and evaluate potential profit opportunities (Kirzner, 1973). Gruber, MacMillan and Thompson (2012) found that experienced entrepreneurs were more likely and better able than novice entrepreneurs to identify market opportunities. In short, experienced entrepreneurs were better able to 'connect the dots' (Baron and Ensley, 2006) than inexperienced entrepreneurs because they were able to identify opportunities earlier (Gaglio and Katz, 2001) and more frequently (Gruber et al, 2012). Equally, to exploit entrepreneurial opportunities, entrepreneurs have to understand their market, the competition they face and provide the service customer's need. These issues are particularly acute in the early stages of a new venture where the impetus is to overcome the 'liability of newness’ (Stinchcombe, 1965). Successful prior entrepreneurial experience may obviate these barriers to business development by increasing comprehension of the tasks required (Dimov, 2010), thereby shortening the time and resources required to meet important developmental 
milestones (e.g. making sales, employing staff) faced by the new venture (Capelleras and Greene, 2008; Forbes, 2005).

Learning by doing experiences (Thompson, 2009) are also potentially invaluable for the resource management of external stakeholders (e.g. customers, suppliers, debt and equity financiers) (Huovinen and Tihula, 2008). A successful track record potentially builds credibility; develops partnerships with customers and suppliers (Ostgaard and Birley, 1994); eases the availability of trade credit finance; and increases the likelihood of accessing of debt and equity finance (Gompers et al, 2010). In sum, relative to novice entrepreneurs, entrepreneurs with prior successful experience have lower start-up costs and have a higher potential to raise startup capital. This is likely to increase venture survival (Plehn-Dujowich, 2010).

Equally, although the successful management of ventures involves managing upsides (i.e. venture survival), it also involves managing downside risks (avoiding bankruptcy). Bates (2005) argues that very many new ventures are, in fact, experiments whereby entrepreneurs pay to 'take a look’ at an entrepreneurial opportunity. Testing a new market opportunity inevitably involves deciding whether to 'stay or quit' (Jovanovic, 1982). Baron and Ensley (2006) also argue that experienced entrepreneurs are more likely to recognize 'danger' than novice entrepreneurs because they focused more on the financial viability of an opportunity rather than its novelty or uniqueness. In general, we hypothesize that the identification, exploitation and resource advantages gained from prior successful entrepreneurial experience are related to higher survival chances and a lower probability of experiencing bankruptcy. We also suggest that there may be differences between portfolio and serial entrepreneurs. Whilst prior experience of success may apply to both portfolio and serial entrepreneurs, we argue that portfolio entrepreneurs are more likely to have greater levels of task specific knowledge derived from a wider and potentially richer experience of different entrepreneurial contexts. Hence, we argue that portfolio entrepreneurs are more likely to have greater experience of conducting and repeating salient venture activities such as identifying opportunities, mobilizing resources and 
developing exploitation strategies. In short, successful portfolio entrepreneurs have greater levels of expert entrepreneurial knowledge. Overall, we hypothesize that, relative to novice entrepreneurs, that success breeds success, particularly for portfolio entrepreneurs.

H1a: Venture survival is more likely for portfolio than novice entrepreneurs;

$H 1 b$ : Portfolio entrepreneurs are less likely than novice entrepreneurs to experience bankruptcy;

H2a: Venture survival is more likely for serial than novice entrepreneurs;

$H 2 b$ : Serial entrepreneurs are less likely than novice entrepreneurs to experience bankruptcy

\subsection{Prior entrepreneurial failure experience}

Entrepreneurial learning theorists have argued that the experience of business failure can also provide a conduit to subsequent business success. Unlike the previously successful entrepreneurs who may be complacent, myopic or fail to experiment sufficiently in their new venture (Sitkin, 1992), entrepreneurial failure is seen as an exemplar of “...discontinuous experiences during the entrepreneurial process [which] can stimulate distinctive forms of higherlevel learning that prove fundamental to the entrepreneur...” (Cope 2011: 2). This is because although prior success can increase the entrepreneurs' confidence in their pre-existing entrepreneurial routines, failure potentially forces the entrepreneur to re-evaluate what is required to be a successful entrepreneur (Minniti and Bygrave, 2001; Politis, 2005). Following on from social learning theory (Bandura, 1997) which emphasises enactive mastery (learning by doing) and vicarious learning (Holcomb, Ireland, Holmes and Hitt, 2009), McGrath (1999) has argued that prior failure promotes better opportunity recognition by increasing the variability of search strategies for new opportunities. It also encourages failed entrepreneurs to understand why their resource and exploitation strategies did not work and what they have to do in a new venture if they are to survive (Politis and Gabrielson, 2009).

However, the experience of prior failure may have persistent consequences on the performance of any new venture (Westhead, Ucbasaran and Wright, 2003). Failed entrepreneurs 
may have fewer resources to call upon in their new venture and find it difficult to leverage the necessary support from external stakeholders (e.g. customers, suppliers, debt and equity financiers) to sustain the new venture. So, although Cope, Cave and Eccles (2004) found that equity financiers were agnostic about the importance of prior failure, the prevailing sense is that failure still carries a stigma (Kirkwood, 2007; Vaillant and Lafuente, 2007) and that survival may be conditional on accessing financial resources.

It may also be the case that previously failed entrepreneurs are again more likely to experience subsequent bankruptcy. There are a number of reasons for this. Learning is difficult (Levinthal and March, 1993), particularly given the heterogeneity and idiosyncratic nature of new opportunities. How experienced entrepreneurs learn may also have less to do with their prior experiences of failure or success, but more with their underlying learning ability (Parker, 2012). Entrepreneurs are also prone to over-optimism (de Meza, 2002) and over-confidence (Hayward, Shepherd and Griffin, 2006) in how they allocate, use and attain resources. This can lead them to deprive their new venture of resources with the net result that it increases the likelihood that they will again go bankrupt. Equally, there is evidence from both entrepreneurial (Cope, 2011; Shepherd, 2003) and corporate (Baumard and Starbuck, 2005; Cannon and Edmondson, 2005) settings which emphasizes that failure does not necessarily lead to changes in behaviour. Attribution theory, in particular, argues that experience of failure do not necessarily lead to subsequent learning. Rather than seeing failure as being due to internal factors (e.g. their ability or efforts), individuals may ascribe failure to external situational factors that are beyond their control. Weiner (1974) also argues that this is likely because individuals often wish to develop positive personal images. Applied to entrepreneurial situations where self-efficacy and over-optimism are potentially important, 'failed' entrepreneurs may not learn from their own failures. In essence, "the mere fact of failing did not result in learning effects” (Neilsen and Sarasvathy, 2011: 4). 
Whilst we recognize the importance of venture finance issues and that learning from failure is potentially difficult, our conjecture is that those with prior failure experience are first more likely to survive than novice entrepreneurs. This is in response to largely qualitative evidence which suggests that failure is likely to breed subsequent success because it forces the previous failed entrepreneur to evaluate how they identify, exploit and manage entrepreneurial opportunities in their new venture. In short, the failure experience changes the way in which these entrepreneurs process information. Instead, of being comfortable with refining previous actions, failure may lead the entrepreneur to search out information in ways that represent a step change from previous activities. Second, we propose that previously failed entrepreneurs are relative to novice entrepreneurs less likely to experience bankruptcy. Again, this argument draws upon theoretical considerations and qualitative empirical evidence which, in the main, suggests that prior experience - particularly of bankruptcy - is so traumatic that in the new focal ventures these entrepreneurs seek to avoid repeating the experience. Hence:

H3a: Venture survival is likely to be higher amongst those with prior failure experience than amongst novice entrepreneurs;

$H 3 b$ : Entrepreneurs who previously failed are less likely than novice entrepreneurs to experience bankruptcy.

\subsection{The mix of prior entrepreneurial success and failure}

One issue that has not, as far as we are aware, been explored in prior entrepreneurship research is the impact of the mix of failed and successful entrepreneurship on venture survival. Diwas et al (2013), argue that the mix of prior success and failure can have positive learning benefits for cardiac surgeons. They show that surgeons are more likely to learn from a mix of their own successes and the failure of other surgeons. Whilst we are unable to assess the impact of failure by other entrepreneurs on our entrepreneurs we argue that the mix of prior success and failure is potentially important in supporting the survival of the focal venture. This is for two reasons. First, as we have already argued, prior success potentially confers reputational and legitimation advantages which may help support the development of the 
new venture. External resource providers such as debt and equity suppliers may recognize these successes and see advantages in supporting the venture. Similarly, prior success may indicate that the entrepreneur has - relative to a novice entrepreneur - the entrepreneurial, managerial and technical ability to identify, exploit and manage opportunities.

Second, the experience of failure which is often traumatic (Cope, 2011) may reduce the myopia, complacency and hubris associated with success, ensuring that in the new venture the entrepreneur devotes sufficient energy and resources to successfully prosecute the business idea (Coelho and McClure, 2005). Hessels, Grilo, Thurik and van der Zwan (2011) also argue that prior failure deepens the human capital stock of the individual and can spur future venture creation. Moreover, whilst failure may make external stakeholders more circumspect about supporting the focal venture, Cope et al (2004) argue that external stakeholders may also recognise that the entrepreneur is 'battle-hardened', particularly as there is a widespread understanding that failure is integral to entrepreneurial dynamics (Houvinen and Tihula, 2008).

Similar to earlier, we also argue that compared to novice entrepreneurs, those with mixed entrepreneurship experience are less likely to experience bankruptcy. Whilst there is contrary evidence that failure experience may be symptomatic of, for example, hubris, we argue that these experienced entrepreneurs are better able to evaluate market opportunities and avoid bankruptcy. Overall, we argue that entrepreneurs with experience of success and failure are more likely to survive and less likely to go bankrupt than novice entrepreneurs because they have specific knowledge of both success and failure.

H4a: Venture survival is likely to be higher amongst those with prior failure/success experience than amongst novice entrepreneurs;

$H 4 b$ : Entrepreneurs with mixed entrepreneurial experience are less likely than novice entrepreneurs to experience bankruptcy 


\section{Data and Methods}

\subsection{Data}

We use data from the first five survey waves (2008-2012) of the KfW/ZEW Start-Up Panel (KfW/ZEW-Gründungspanel). This is a unique panel data set on newly founded ventures in Germany. The panel was established in 2008 by the Centre for European Economic Research (ZEW), KfW Bankengruppe (Germany’s largest state owned promotional bank) and Creditreform (Germany's largest credit rating agency). These data are collected using computer-aided telephone interviews and have a target of approximately 6,000 interviews per annum. In overall terms, the KfW/ZEW Start-Up Panel is the most comprehensive database of German new ventures.

The sampling frame of the KfW/ZEW Start-Up Panel is the Mannheim Enterprise Panel (MUP). The MUP covers almost all firms in Germany and is built from the database of Creditreform (Almus, Engel and Prantl, 2000). Besides information on venture stocks, the MUP also includes information on start-ups, bankruptcies and voluntary closures. These data are updated annually. The statistical unit of the KfW/ZEW Start-Up Panel is the legally independent venture. Merger activities and subsidiary businesses are excluded from the survey. The sample is stratified according to three criteria: (i) year of firm formation, (ii) industry, and (iii) whether or not the firm has received financial support by KfW. Each year, a random sample of new ventures is drawn from the MUP which have been founded during the three years prior to the year of the survey. Selected ventures are subsequently followed over successive panel waves until they are eight years old.

The first five waves of the KfW/ZEW Start-up Panel contain information on entrepreneurial characteristics (e.g. educational background, gender, prior employment status, managerial and leadership experience, prior entrepreneurial experience), venture finance characteristics (e.g. amount of investments and current costs, financing sources and structure), and venture characteristics (e.g. start-up size, number of employees) on 13,000 new ventures. Infor- 
mation on venture survival outcomes is derived from the MUP. In this paper, we restrict our sample to ventures founded by a single founder because the data does not allow us to specifically identify which of the founders has prior entrepreneurial experience in team-based new ventures. In order to avoid these confounding effects, we restricted our sample to solo entrepreneurial ventures. This gives us a sample of 8,400 new ventures which is $70 \%$ of the total sample ${ }^{1}$.

\subsection{Measures}

\subsubsection{Dependent variables}

We use two dependent variables. First, in common with a range of other studies (see reviews by Parker, 2009; Storey and Greene, 2010), we measure survival if a venture has survived until year $\mathrm{j}-1$, where $\mathrm{j}$ is the survey year and $\mathrm{j}-1$ is the reporting year. In total, as Table 1 shows, the survival rate is $89 \%$. Second, we differentiate the non-surviving ventures between those that go bankrupt (4\%) and those that close voluntarily (7\%).

\subsubsection{Predictor Covariates: Prior experience of failure and success}

We use four measures of prior entrepreneurial experience. Prior experience of successful entrepreneurship is measured in two ways: PORTFOLIO (1=currently running more than one venture besides the focal venture, $0=$ otherwise); and SERIAL (1=previously sold/transferred a venture; $0=$ otherwise). Failed entrepreneurs (FAILURE) are those entrepreneurs who had previously run a venture that went bankrupt or was voluntary dissolved ( $0=$ otherwise). The final measure of prior entrepreneurial experience includes entrepreneurs who have prior experience of both failure and success (MIX_EXP). Table 1 shows that 11\% of all entrepreneurs are failed entrepreneurs, $9 \%$ are portfolio, 6\% are serial entrepreneurs,

\footnotetext{
${ }^{1}$ This is representative of German new ventures since around 75\% of the ventures are set up by solo entrepreneurs.
} 
and $1 \%$ have 'mixed' experiences. In sum, more than a quarter of the new ventures are founded by entrepreneurs with prior entrepreneurial experience.

\subsubsection{Control variables}

Table 1 also details a range of entrepreneur, venture, sectoral and vintage controls that are commonly associated with survival. In terms of entrepreneurial characteristics, Lin, Picot and Compton (2000) and Bates (1995) found that the better educated (measured by 1=DEGREE, $0=$ otherwise and higher vocational qualifications (1=MASTERCRAFT, $0=$ otherwise)); those with prior industrial (log of number of years) (van Praag, 2003) or with managerial experience (1=MANAGE_EXP, $0=$ otherwise) (Taylor, 1999), are more likely to survive. There is also clear evidence that survival often follows an inverted U-shaped pattern with respect to the age of the entrepreneur, with ventures run by younger and older aged individuals less likely to survive (Bates, 1995; van Praag, 2003) (log of entrepreneur's age and age squared (AGE and AGE2)). Women (1=FEMALE, $0=$ otherwise) are also less likely to experience survival (Honjo, 2000). Finally, Shane, Locke, Collins (2003) identify that venture survival also depends on entrepreneurial motivations. We distinguish between those entrepreneurs who created their venture in response to the identification of a market gap (1=OPPORTUNITY, $0=$ otherwise), because of the absence of alternative opportunities, (1=NECESSITY, $0=$ otherwise) or to achieve independence (1=INDEPENDENCE, $0=$ otherwise (base category)). Table 1 shows that $14 \%$ of venture founders are female, that the average age is 41 years, and that $31 \%$ and $29 \%$ have a degree or a higher vocational qualification, respectively. Mean years of industrial experience is 15 years with $37 \%$ having prior managerial experience. $27 \%$ are motivated by opportunity whilst a further $19 \%$ set the venture up out of necessity.

In terms of venture characteristics, evidence suggests that limited companies (1=LTD, $0=$ otherwise), those that conduct research and development ( $\& D=1,0=$ otherwise) and big- 
ger ventures are more likely to survive (SIZE, SIZE2). So, too, are better capitalized ventures (logarithm of the total amount of investments in the reporting year (INV)) ${ }^{2}$; those which have access to external finance from the government ( $1=$ PUBLIC, $0=$ otherwise) or from external investors (share of external financing (EXTERNAL)). Also important is the availability of internal financing through retained earnings (share of cash flow on total financing (RETAINED)), and if the venture experienced financial problems (1=FIN_PROBLEMS, 0=otherwise). Prior studies (Geroski, 1995; Santarelli and Vivarelli, 2007; Parker, 2009; Geroski, Mata and Portugal, 2010 and Storey and Greene, 2010) show that these factors influence venture survival). Table 1 shows that the average venture size is 3.4 employees (including the founder) with a quarter (27\%) being a limited company and $18 \%$ conducting $R \& D$. Table 1 also shows that 16\% of founders experienced financial problems, that 34\% used government support; that, on average, $66 \%$ of ventures used retained earnings to fund their investments; $13 \%$ of outside financing stemmed from external sources (banks, funding or private investors); and that ventures invested $€ 35,000$ annually. Finally, we include a range of sectoral dummies: new technology based manufacturing (divided into 'cutting edge technology' (CET) (base category) and 'high technology' (HT)); non-high-tech manufacturing (OTHER_MANU); high-tech services (NTB_SERVICES, SOFTWARE), CONSTRUCTION, knowledge-intensive services (KNOW_SERVICES), and consumer related services (CONSUME_SERVICES, OTHER_SERVICES and RETAIL) and controls for the start-up year in the estimations. The most common sectors are new technology based services (20\%), retail (16\%), consumer services (13\%) and construction (13\%) whilst the most common years of founding are 2006 and 2007.

\footnotetext{
${ }^{2}$ We replace INV $=\log (0.0001)$ if investments are zero, otherwise we would lose the observation of the venture in the reporting year. We add a control variable indicating that investments are zero for that observation (INV DUM).
} 
To estimate survival time of the ventures we use two duration models. The first is a single risk model where we only account for the fact whether a firm has survived or not. Whilst survival time is continuous, we only observe if the venture still exists at the end of the year, i.e. spell lengths are only observed in intervals. We therefore estimate a model for interval censored data. The relevant hazard rate is the probability of exit during year $j$ given survival up to year $j-1$

$$
h_{j}(X)=P(j-1<T \leq j \mid T>j-1, X) \text {, }
$$

where $\mathrm{j}$ denotes the half-open interval $\left(\right.$ year $_{j-1} ;$ year $\left._{j}\right]$. The dependent variable contains the information whether or not venture $i$ survived year $j$

$$
S_{i j}=\left\{\begin{array}{l}
1 \text { if firm } i \text { survives year } j \\
0 \text { if firm } i \text { does not survive year } j
\end{array}\right.
$$

Duration models based on this type of data can be estimated by applying methods for standard binary outcome models (Sueyoshi, 1995; and Jenkins, 2005). As functional form for the hazard rate we use a complementary log-log specification ${ }^{3}$ and allow for both timeinvariant and time-variant covariates. The hazard rate can then be expressed as

$$
\log \left[-\log \left(1-h_{i j}\right)\right]=\beta_{0}+\beta^{\prime}{ }_{1} X_{i}+\beta^{\prime}{ }_{2} Z_{i j}+u_{i}
$$

where $X^{\prime}$ is a matrix of time-invariant explanatory variables and $Z_{t}^{\prime}$ is a matrix of time-variant explanatory variables and $u_{i}$ is the random intercept of firm $i$. In order to allow the hazard rate to vary with survival time (duration dependence), year dummies are added to the list of regressors.

To account for venture heterogeneity not captured by the observed variables, the complementary log-log model is estimated with random effects so that for binary variables the unobservable firm effect $u_{i}$ is sampled along with the dependent variable and observable in-

\footnotetext{
${ }^{3}$ In principle, any continuous distribution function can be used but Greene (2000: 815) shows that the results of binary choice models are not very sensitive to the functional form of the distribution functions.
} 
dependent variables and it is removed by integrating it out (Wooldridge, 2002: 482). Here, the distribution of $u_{i}$ is assumed to be $N \sim\left(0, \sigma_{u}\right)$.

Our second duration model is a competing risk model in which we assess whether the different types of entrepreneurial experience have different effects on the two types of closure (voluntary dissolution and bankruptcy). Because of the way survival time is reported in our data we again use a model for interval censored data. The dependent variable is

$$
S_{i j}=\left\{\begin{array}{l}
0 \text { if firm } i \text { survives year } j \\
1 \text { if firm } i \text { voluntarily exits in year } j \\
2 \text { if firm } i \text { goes bankrupt in year } j
\end{array}\right.
$$

It can be shown that a competing risk model with interval censored data can be estimated by applying a standard multinomial logit model (Allison, 1982: Jenkins, 2005). The destination specific hazard for the two exit states in this case are assumed to be

$$
h_{v d}=\frac{\exp \left(\beta^{\prime}{ }_{v d} X\right)}{1+\exp \left(\beta^{\prime}{ }_{v d} X\right)+\exp \left(\beta^{\prime}{ }_{b} X\right)}
$$

and

$$
h_{b}=\frac{\exp \left(\beta^{\prime}{ }_{b} X\right)}{1+\exp \left(\beta^{\prime}{ }_{v d} X\right)+\exp \left(\beta^{\prime}{ }_{b} X\right)},
$$

where $v d=$ voluntary dissolution and $b=$ bankruptcy. Duration dependence is accounted for by including year dummies in the list of regressors as above.

\section{Results}

Our results are organised into six tables. Table 1 shows summary statistics and presents the results of simple T-tests that - against a range of entrepreneurial and venture characteristics - compare our four types of prior entrepreneurial experience with novice entrepreneurs. Table 2 shows correlation coefficients. These are generally modest and we detected no signs of collinearity which might impact on our subsequent econometric analysis.

In Table 3, we present two models. The first model presents the base model results for our survival time model (non/survival). The second model responds to Eesley and Roberts 
(2012) and Toft-Kehler et al (2013) who showed that industrial experience, education and financial capital can impact on the relationship between entrepreneurial experience and survival. Model 2 in Table 3 examines if these factors influence the relationship between entrepreneurial experience and survival outcomes. Table 4 ccomplements these results by, first, restricting the sample to prior failed entrepreneurs and, second, to high-technology ventures in order to find out whether the effects of prior entrepreneurial experience is different for entrepreneurs who already failed once and for high-tech firms. Table 5 presents the results of the competing risk model which differentiates between voluntary dissolution and bankruptcy outcomes in the focal venture both in terms of the base model (Model 1) and in terms of the influence of financial capital, industrial experience and education (Model 2). Finally, Table 6 show the results of our competing risk models for the restricted samples (prior failed entrepreneurs and high-tech ventures).

The T-test results in Table 1 identify interesting differences between novice and our four groups of experienced entrepreneurs. Relative to novices, experienced entrepreneurs are more likely to be highly educated (DEGREE), be older, have greater industry experience, are more likely to set up as a limited company, be located in high-tech sectors, and conduct R\&D. They are also more likely to be OPPORTUNITY rather than NECESSITY entrepreneurs. Furthermore, PORTFOLIO and SERIAL entrepreneurs have on average more employees and have higher yearly investments than novice entrepreneurs. In contrast, experienced entrepreneurs are less likely - relative to novice entrepreneurs - to be women, to have managerial experience, be in construction, and receive public funding for their venture. One final difference between novice and experienced entrepreneurs is that novice entrepreneurs are less likely to experience financial problems. These are differences that we return to after we have presented our multivariate results.

Tables 1 and 2 about here 
Table 3 presents the results of the binary survival duration model (non/survival). In terms of our specific hypotheses, Table 3 shows that there is no evidence that portfolios or serials are more likely to survive. We, therefore, reject H1a and H2a. We also find no evidence to support H4a that 'mixed' entrepreneurs are more likely to survive than novices. However, Table 3 shows that those with prior experience of entrepreneurial failure are less likely to survive. We reject H3a. Model 2 in Table 3 also shows that financial capital and industrial experience are insignificant. The only significant interaction term is if failed entrepreneurs have a degree, indicating that venture survival is more likely amongst failures with a higher degree.

With respect to the control variables, there is evidence of an inverted U-shaped pattern effect for entrepreneurial age; and that those with master craft level qualifications and sectoral experience are more likely to survive. Necessity entrepreneurs are less likely to survive. The other controls that impact on survival in Table 3 are financial factors. Those ventures that have greater levels of investment, received public financial support and use greater shares of inside financing are all more likely to survive. Those with financial problems are less likely to survive.

\section{Table 3 about here}

In order to learn more about different subgroups of new ventures we restrict the sample in two ways. First, given that failed entrepreneurs are significantly less likely to survive, we investigate in Model 1, Table 4 which characteristics of the entrepreneur and its venture are associated with closing again. The results show an inverted U-shaped age effect and that those with prior managerial experience are less likely to survive. Women are also less likely to survive. So, too, are those experiencing financial problems. Perhaps the most interesting 
result in Table 4 is that OPPORTUNITY based entrepreneurs are less likely to survive ${ }^{4}$. Second, because our firms include a number of high-tech ventures, we restricted the sample to high-tech ventures to see if there are evident differences between all and high-tech ventures. Following on from the NACE (revision 1) classification, high-tech ventures are defined in terms of high-tech manufacturing (NTB_MANU: CET and HT), knowledge intensive services (NTB_SERVICES) and SOFTWARE sectors. Model 2 in Table 4 shows that none of the key prior entrepreneurship experience variables are significant, either positively or negatively. Hence, although FAILURE remains negative (as does MIX_EXP), it is no longer significant. Similarly, although PORTFOLIO and SERIAL are positive, these results are insignificant. Overall, there is little in Table 5 to suggest that prior entrepreneurial experience promotes venture survival even amongst high-tech ventures.

\section{Table 4}

Table 5 shows our results from the competing risks model. In terms of voluntary dissolution, none of the four key measures of entrepreneurial experience are significant. In terms of bankruptcy, we again find no evidence to support H1b or H2b. We also find that those with prior experience of failure and those with mixed experience are both more likely to become bankrupt than novice entrepreneurs. We reject H3b and H4b. As with before, we also examine in Table 5, the influence that education, industrial experience and financial capital have on the relationship between venture outcomes and entrepreneurial experience. In terms of bankruptcy, none of the interaction terms are significant. Voluntary dissolution is, however, less likely amongst those with a degree/failure experience but more likely amongst financial capital/mixed entrepreneurial backgrounds.

Table 5 about here

\footnotetext{
${ }^{4}$ The significant negative effect of FEMALE and OPPORTUNITY on survival can only be observed amongst those with prior failure experience, but not within the group of founders with successful entrepreneurial experience (results are available on request from the authors).
} 
In Table 6 we again restrict the samples to failed entrepreneurs and high-tech ventures. Model 1 shows previously failed necessity entrepreneurs more likely to face bankruptcy, whereas failed opportunity entrepreneurs are more likely to voluntarily dissolve their venture. In terms of high tech ventures (Model 2), there is evidence that failed entrepreneurs and those with mixed experience were more often likely to go bankrupt. These results are similar to Table 5 for the total sample.

\section{Table 6 about here}

\section{Discussion}

\subsection{Key Findings}

This paper responds to the call by Ucbasaran et al (2013) to use large scale panel data to investigate if there are positive path dependencies between prior entrepreneurial experience and venture survival. Essentially, the key advantage of prior experience is that the repetition of opportunity seeking activities reduces the costs of start-up, thereby increasing the likelihood of better survival outcomes (Plehn-Dujowich, 2010). In contrast, the alternative argument is that learning either reflects underlying human capital abilities or is made more difficult to achieve by the idiosyncratic nature of opportunities (Frankish et al, 2012) and, as attribution theory suggests, the difficulties that individuals have in correctly interpreting past instances of entrepreneurial failure and success. One key advantage of our panel data is that we can control for a range of factors that are commonly associated with venture survival. Of these, perhaps the most important are venture finance characteristics since prior research has indicated that prior experiences of bankruptcy can take years to clear (Cope, 2011) or, for successful entrepreneurs, provide them with access to resources (Gompers et al, 2010).

Our key findings are that both portfolio and serial entrepreneurs are no more likely to survive in the new venture; nor were they more likely to avoid bankruptcy than novice entrepreneurs. Those with mixed experience are more likely than novice entrepreneurs to experience subsequent bankruptcy. Previously failed entrepreneurs were found to be less likely to 
survive and more likely to face bankruptcy. There is little overall evidence to suggest that financial capital, industrial experience or education have an influential impact on the relationship between venture outcomes and entrepreneurial experience. In essence, our results indicate a path dependency: if at first an entrepreneur fails, then the most likely outcome is bankruptcy. Within these overall findings, we also find interesting sub-sample results. We find previously failed entrepreneurs who are motivated in the focal venture by opportunity are less likely to survive. We also find that failed necessity motivated entrepreneurs are more likely to go bankrupt.

Our results also show that venture finance characteristics are important indicators of the propensity of venture survival and bankruptcy outcomes. In particular, ventures that experience financial problems and have fewer financial resources are less likely to experience efficacious venture survival outcomes. We also find that necessity entrepreneurs are less likely to survive and more likely to become bankrupt. These results reiterate the importance of financial resources to survival outcomes and that necessity entrepreneurs are more likely to experience negative venture outcomes (Parker, 2009; Storey and Greene, 2010).

\subsection{Theoretical implications}

There has been considerable theoretical and empirical debate about the worth of entrepreneurial experience to future venture outcomes. Some theoretic pieces remain optimistic, arguing that prior entrepreneurial experiences can prepare entrepreneurs for future success in their new focal venture (Cope, 2011; McGrath, 1999) because such experiences provides a repertoire of skills and knowledge that allow experienced entrepreneurs to identify and exploit opportunities (Baron and Ensley, 2006). Others are perhaps more equivocal, given that they recognize that whilst prior experience may provide assets it often brings with it liabilities which may prevent the full exploitation of these knowledge stocks (Holcomb et al, 2009). Hence, failed entrepreneurs may find it difficult to learn from their prior experiences (Shep- 
herd, 2003) perhaps because they are prone to particular cognitive biases (e.g. over-optimism) (Hayward et al, 2006), because it is difficult to apply prior experience to novel entrepreneurial situations (Frankish et al, 2012) or because they attribute failure to external situational factors rather than underlying issues in terms of effort or ability (Diwas et al, 2013). A more pessimistic view of experience, however, is that what actually matters more than experience is the underlying entrepreneurial talent of the entrepreneur to venture outcomes (Rocha et al, 2013; Chen, 2013).

Within these competing theoretical stances, our results provide fresh insights into the role that prior entrepreneurial experience plays in venture survival. One of the problems with the popular anecdotal view of the importance of prior entrepreneurial experience is that failure, in particular, is almost a 'rites of passage', representing "an essential pre-requisite for learning and adaptation” (Sitkin, 1992: 231). Our findings do not support this view for any of the types of entrepreneurial experience we considered. This, of course, does not imply that entrepreneurs do not learn, either from prior success or failure. Nor would we want our results to imply that entrepreneurs do not attempt to apply their experiences - either positive or negative - in their new focal venture. Instead, our results have three implications for understanding new venture activities.

First, because market opportunities are idiosyncratic, there are limits to the applicability of a prior repertoire of experiences. Our results, therefore, support prior evidence that has identified that it is difficult for experienced entrepreneur to apply what they learnt from past actions into new business situations (Frankish et al, 2012; Parker 2012). In other words, entrepreneurial experience may provide assets but these assets are often unrealisable when faced with the endemic uncertainty of entrepreneurship.

Second, rather than focusing on assets, our results stress the liabilities of entrepreneurial experience. Wright, Robbie and Ennew (1997) suggested that relying on previously learnt behaviours and attitudes can be harmful since they can lead to costly errors. Our findings - 
particularly in terms of the sub-sample analyses of the motivational profiles of previously failed entrepreneurs - certainly chime with other evidence which reports that failed entrepreneurs can find it difficult to apply their experiences to their new focal firm. Whilst our data only allow us to draw inferences, one candidate explanation is the importance of cognitive biases in entrepreneurial settings. Although being over-optimistic is beneficial at start-up in propelling the venture forward, what our findings imply is that failed entrepreneurs can mistake tenacity for what is an unwarranted 'escalation of commitment' (Davidsson and Gordon, 2012). Entrepreneurs may also fall into competency traps (March, 1991) which stymies their ability to learn but may not inhibit their willingness to take excessive risks. In sum, although we recognize that prior entrepreneurial experience can provide assets (Politis, 2005), such experiences do not necessarily lead to positive outcomes (Levinthal \& March, 1993) and may "cause an entrepreneur to overlook or discard objective information, even when conditions of a class of events have changed” (Holcomb et al, 2009: 182). This presents a challenge to entrepreneurship scholars. Similar to the insights afforded by the grief literature on entrepreneurial failure (Shepherd, 2003), there is a need for a more careful understanding of the liabilities of entrepreneurial experience and what impedes the efficacy of entrepreneurial experience. Our sub-sample evidence begins to identify that there are different motivational profiles associated with those who are more likely to experience poorer venture survival outcomes but we call for further research that combines our focus on entrepreneurial outcomes with an examination of the pathways which may hinder or promote entrepreneurial learning.

Finally, our results emphasize the importance of ability over experience. We find that education rather than industrial experience or financial capital moderate the relationship between experience and survival outcomes. Whilst we accept that cognitive and learning abilities is heterogeneous (Schmidt and Hunter, 2004), we also concur with a view that sees learning being shaped more by underlying innate and deep-rooted socio-economic factors (Parker, 2012) than transient performance outcomes. Regardless of if entrepreneurs are liable to put 
their prior (failure) success down to themselves or (bad) luck, our findings are more in step with a view that it is entrepreneurial ability rather than learning by doing gained by prior experience that explains venture survival and bankruptcy outcomes.

\subsection{Limitations}

Despite using large scale panel data, our study does have a number of limitations. First, we know that institutional and cultural factors are influential in promoting or inhibiting particular attitudes to entrepreneurial failure. Kirkwood (2007) identifies that countries such as New Zealand suffers from a ‘tall poppy’ syndrome (knocking of high achievers). Hence, although our results are in line with Frankish et al (2012) UK data and Parker (2012) who finds for the US that the value of entrepreneurial experience quickly decays, it may be that German entrepreneurs face particular cultural and institutional challenges that are absent elsewhere. In particular, whilst failure is stigmatized in parts of the United States (Cardon, Stevens and Potter, 2011) a distinction is often drawn between European and United States in terms of 'fear of failure’ (European Commission, 2010) whilst Klein and Helweg-Larsen (2002) identify that Americans are more prone to over-optimism. We would, therefore, like to see comparative research that investigated international differences.

Our study also only examines types of entrepreneurial experience rather than the nature of these entrepreneurial experiences (Westhead and Wright, 2011). Hence, our data are silent on what impact different forms of learning (direct experience, vicarious or codified) have on these outcomes. Moreover, although we show that necessity entrepreneurs are more likely to experience poorer survival outcomes, our data does not allow us to investigate the ambitions for the new venture. Portfolio entrepreneurs, for example, may have been distracted by their other business commitments, limiting their ability to nurture the focal venture. Similarly, whilst some previously failed entrepreneurs may be presumed to be financially conservative in the focal venture, it may be that such entrepreneurs adopt instead a high risk 'double or 
bust' strategy. As implied earlier, this suggests a need for a mixed method approach that longitudinally focuses on the outcomes of and learning processes used by experienced entrepreneurs.

Understanding business closure/failure is hampered by the profusions of associated terms (e.g. discontinuance, death, closure, failure, exit, bankruptcy) (Watson and Everett, 1996; Coad, 2013) and the fact that not all closures are, in fact, failures (Headd, 2003). Whilst this study has sought to examine two common dimensions of business closure/failure (voluntary dissolution and bankruptcy), there is a need to extend research that examines different subgroups of voluntary closure (Wennberg et al, 2010) and to more fully distinguish between those that previously either went bankrupt or chose voluntary dissolution. In tandem with this, there is a further need to examine, using similar longitudinal data, the impact of prior experience on venture growth outcomes. Survival may be the cardinal business objective but as scholars, policy makers and practitioners we are often keen to establish what factors are likely to promote venture performance. This again needs to be done within a longitudinal setting. Similarly, because our data does not allow us to examine the profiles of each individual team member (whether as an owner or employee), we have focused on solo entrepreneurs where we know their prior experience. Future research could also further examine team entrepreneurship (Stam and Schutjens, 2005) and how differing entrepreneurial experiences within the team influence venture performance.

One final limitation of this study is that it suffers from a selection bias in that we do not have information in the KFW/ZEW Start-up Panel on formerly failed entrepreneurs who decided not to re-enter entrepreneurship. We cannot ignore the potential that our failed entrepreneurs who, on average, fail again are drawn from a sub-sample of individuals who - relative to those that having failed realise that entrepreneurship is not for them - have either few alternative choices or are prone to cognitive biases. This is an avenue for future research. 


\subsection{Implications for policy and practice}

For practitioners, our results raise important issues about entrepreneurial re-entry decisions. Our findings imply that successful entrepreneurs do not necessarily translate their experiences successfully in to their new venture. This calls on them to carefully evaluate any new opportunity and to challenge the routines that they have previously adopted. One way of achieving this is to consider business planning activities which have been shown to improve decision making processes in entrepreneurial settings (Delmar and Shane, 2003). These results may also encourage both successful and failed entrepreneurs to consider counterfactual thinking strategies. We, therefore, join with Ucbasaran et al (2013) in urging failed entrepreneurs and other experienced entrepreneurs to consider how they make sense of their prior ex-

periences. We know that cognitive biases are persistent features of entrepreneurial activity (Landier and Thesmar, 2009) and, as our results imply, they are less able if anything to recognize their limitations than first-time entrepreneurs. As such, prior entrepreneurs need to develop heterophily rather than homophily by building businesses that rely on diverse teams and outside mentors. This may aid the development of counter-factual thinking and allow entrepreneurs to develop more realistic sense-making activities and stories about the financial health and well-being of their venture (Rosenzweig, 2007).

As for policy makers, prior studies have provided competing interpretations of the value of relaxed bankruptcy laws. Some studies show that that looser bankruptcy laws can promote entrepreneurial entry (Lee et al, 2007, 2011) whilst de Meza (2002) and de Meza and Southey (1996) argue that relaxed entry conditions encourage unsuited individuals into entrepreneurship. Our longitudinal evidence supports the latter interpretation of de Meza (2002). We find that failure begets failure rather than breeds success. We encourage policy makers to take note of these findings and consider the implications they have for their own bankruptcy laws. 


\section{Conclusions}

This study has investigated the path dependencies between four differing types of entrepreneurial experience and venture survival outcomes. Such a study is important because the ongoing theoretical and empirical debate about the efficacy of entrepreneurial experience. Our panel data study of 8,400 solo entrepreneurs uses a wide range of entrepreneurial, financial and venture level characteristics. Using survival duration models, our results showed that venture survival outcomes are unrelated to prior successful entrepreneurial experience and that failed entrepreneurs are more likely to fail again. These findings point to implications for scholars, entrepreneurs and policy makers and highlight the need for further research. 


\section{References}

Allison, P. 1982. Discrete time methods for the analysis of event histories, in S. Leinhardt ed. Sociological Methodology, Jossey-Bass, San Francisco, 61-98.

Almus, M., D. Engel and S. Prantl 2000. The Mannheim Foundation Panels of the Centre for European Economic Research ZEW , ZEW Documentation 00-02, ZEW, Mannheim.

Autio, E and Pathak, S. 2010. Entrepreneur's exit experience and growth aspirations, Frontiers of Entrepreneurship Research, 30:5, Article 2.

Bandura, A. 1997. Self-efficacy: The exercise of control, New York: Freeman.

Baron, R.A., and Ensley, M.D. 2006. Opportunity recognition as the detection of meaningful patterns: evidence from comparisons of novice and experienced entrepreneurs. Management Science 529 , 1331-1344.

Bates, T. 1995. Analysis of Survival Rates among Franchise and Independent Small Business Startups. Journal of Small Business Management, 332 , 26-36.

Bates, T. 2005. Analysis of young, small firms that have closed: delineating successful from unsuccessful closures. Journal of Business Venturing, 203 , 343-358.

Baumard, P. and Starbuck, W.H. 2005. Learning from failures: why it may not happen. Long Range Planning 383 , 281-298.

Blackburn, R. and Kovalainen, A.K. 2009. Researching Small Firms and Entrepreneurship: Past, Present and Future, International Journal of Management Reviews, 112 , 127-48.

Cannon, M.D., andEdmondson, A.M., 2005. Failing to learn and learning to fail intelligently : how great organizations put failure to work to innovate and improve. Long Range Planning 382 , 299-319.

Capelleras, J. L., and Greene, F. J. 2008. The determinants and growth implications of venture creation speed. Entrepreneurship and Regional Development, 204 , 317-343.

Cardon, M. S., Stevens, C. E., and Potter, D. R. 2011. Misfortunes or mistakes? Cultural sensemaking of entrepreneurial failure. Journal of Business Venturing, 261 , 79-92.

Cardon, M. and McGrath, R.G. 1999. When the going gets tough..Toward a psychology of entrepreneurial failure and re-motivation, paper presented at the Frontiers of Entrepreneurship Research Conference, Babson College.

Carter, R., and Van Auken, H. 2006. Small firm bankruptcy. Journal of Small Business Management, 444 , 493-512.

Coad, A. 2013. Death is not a success: Reflections on business exit, published online 25 February 2013 International Small Business Journal.

Coelho, P.R.P. and McClure, J.E., 2005. Learning from failure. Mid-American Journal of Business 201 , 13-20.

Cope, J., Cave, F., and Eccles, S. 2004. Attitudes of venture capital investors towards entrepreneurs with previous business failure. Venture Capital, 6 2/3 : 147-172.

Cope, J. 2011 Entrepreneurial learning from failure: An interpretative phenomenological analysis, Journal of Business Venturing 26, 604-62

Corbett, A. C. 2005. Experiential learning within the process of opportunity identification and exploitation. Entrepreneurship Theory and Practice, 294 , 473-491.

Corbett, A. C. 2007. Learning asymmetries and the discovery of entrepreneurial opportunities. Journal of Business Venturing, 221 , 97-118.

Davidsson, P., and Gordon, S. R. 2012. Panel studies of new venture creation: a methodsfocused review and suggestions for future research. Small Business Economics, 394 , 853876.

de Meza, D 2002. Overlending, Economic Journal, 112:477, February, F17-F31.

de Meza, D and Southey, C. 1996. The Borrowers Curse: Optimism, Finance And Entrepreneurship, Economic Journal, 109, 153-163.

DeTienne, D.R. 2010. Entrepreneurial Exit as a Critical Component of the Entrepreneurial Process: Theoretical Development. Journal of Business Venturing, 25:2, 203-15. 
Delmar, F. and Shane, S. 2003. Does business planning facilitate the development of new ventures? Strategic Management Journal, 2412 , 1165-1185.

Dimov D. 2010. Nascent entrepreneurs and venture emergence: Opportunity confidence, human capital, and early planning. Journal of Management Studies, 476 : 1123-1153.

Diwas, K.C. Staats, B.R. and F. Gino 2013 Learning from My Success and from Others' Failure: Evidence from Minimally Invasive Cardiac Surgery, Management Science, Articles in Advance, pp. 1-15.

Eesley C., Roberts E.B., 2012. Are You Experienced or Are You Talented?: When Does Innate Talent vs. Experience Explain Entrepreneurial Performance? Strategic Entrepreneurship Journal.

European Commission 2010. Flash EB Series \#283, Entrepreneurship in the EU and beyond, Brussels: European Commission.

European Commission 2003. Green Paper: Entrepreneurship in Europe, Brussels: European Commission.

Forbes, D. P. 2005. Managerial determinants of decision speed in new ventures. Strategic Management Journal, 264 , 355-366.

Frankish, J.S., Roberts, R.G., Coad, A., Spears, T.C. and Storey, D.J. 2012. Do entrepreneurs really learn? Or do they just tell us that they do? Industrial and Corporate Change. 14643650

Fraser, S. and Greene, F. J. 2006. The effects of experience on entrepreneurial optimism and uncertainty. Economica, 73290 , 169-192.

Gaglio, C. M., and Katz, J. A. 2001. The psychological basis of opportunity identification: Entrepreneurial alertness. Small Business Economics, 162 , 95-111.

Geroski, P.A., J. Mata, and P. Portugal 2010. Founding Conditions and the Survival of New Firms. Strategic Management Journal, 31:5, 510-29.

Geroski, P.A. 1995. What do We Know about Entry?, International Journal of Industrial Organization, 13, 421-440.

Gimeno, J., Folta, T. B., Cooper, A. C., and Woo, C. Y. 1997. Survival of the fittest? Entrepreneurial human capital and the persistence of underperforming firms. Administrative Science Quarterly, 42 4 , 750-783.

Gompers, P.A., J. Lerner, D. Scharfstein, and A. Kovner 2010. Performance Persistence in Entrepreneurship and Venture Capital, Journal of Financial Economics 96 1, 18-32.

Greene, W. 2000. Econometric analysis. Upper Saddle River, NJ: Prentice Hall.

Gruber, M., MacMillan, I. C. and Thompson, J. D. 2012. From Minds to Markets: How Human Capital Endowments Shape Market Opportunity Identification of Technology Start-Ups. Journal of Management, 385 , 1421-1449.

Hayward, M. L. A., Shepherd, D. A., \& Griffin, D. 2006. A hubris theory of entrepreneurship. Management Science, 522 , 160-172.

Headd, B. 2003. Redefining business success: Distinguishing between closure and failure. Small Business Economics, 21 , 51-61.

Hessels, J., Grilo, I., Thurik, R., \& van der Zwan, P. 2011. Entrepreneurial exit and entrepreneurial engagement. Journal of Evolutionary Economics, $213:$ 447-471.

Holcomb, T. R., Ireland, R. D., Holmes, R. M., Jr., and Hitt, M. A. 2009. Architecture of Entrepreneurial Learning: Exploring the Link Among Heuristics, Knowledge, and Action. Entrepreneurship Theory and Practice, 331 , 167-192.

Honjo, Y. 2000 Business failure of new firms: an empirical analysis using a multiplicative hazards model, International Journal of Industrial Organisation, 18:4, 557-574.

Huovinen, J. \& Tihula, S. 2008. Entrerpeneurial learning in the context of portfolio entrerpeneurship. International Journal of Entrerpeneurial Behaviour \& Research. 14 : 152-171. Jenkins, S. 2005. Survival Analysis. Institute for Social and Economic Research, University of Essex, Colchester, UK. 
Jovanovic, B. 1982. Selection and the Evolution of Industry, Econometrica, 50:3, 649-670.

Kahneman D., Slovic P., Tversky A., 1982. Judgment under uncertainty: Heuristics and biases. Cambridge University Press.

Kirkwood, J. 2007. Tall Poppy Syndrome: Implications for entrepreneurship in New Zealand. Journal of Management \& Organization, 134 : 366-382.

Klein, C. T. F., and Helweg-Larsen, M. 2002. Perceived control and the optimistic bias: A meta-analytic review. Psychology and Health, 17, 437-446.

Kirzner, I.M. 1973. Competition and Entrepreneurship, Chicago: University of Chicago Press.

Knaup, A., and M. Piazza 2007. Business Employment Dynamics Data: Survival and Longevity, II, Monthly Labor Review 1309 , 3-10.

Landier, A. and Thesmar, D. 2009. Financial Contracting with Optimistic Entrepreneurs, The Review of Financial Studies, 22:1, 117-150.

Lee, S.-H., Yamakawa, Y., Peng, M., \& Barney, J. 2011. How do bankruptcy laws affect entrepreneurship development around the world? Journal of Business Venturing, 26: 505-520.

Lee, S.-H., Peng, M., and Barney, J. 2007. Bankruptcy law and entrepreneurship development: A real options perspective. Academy of Management Review, 32: 257-272.

Levinthal, D.A. \& March, J. 1993. The myopia of learning. Strategic Management Journal, 14, 95-112.

Lin, Z. X., Picot, G., and Compton, J. 2000. The entry and exit dynamics of self-employment in Canada. Small Business Economics, 152 , 105-125.

March J.G., 2010. The ambiguities of experience. Cornell Univ Press.

March, J.G., 1991. Exploration and exploitation in organizational learning. Organization Science 2, 71-87.

Mazur J., 1994. Learning and Behavior. Englewood Cliffs, NJ: Prentice-Hall.

McGrath, R.G. 1999. Falling forward: Real options reasoning and entrepreneurial failure, Academy of Management Review, 24:1, 13-30.

Minniti, M. and W. Bygrave 2001. A Dynamic Model of Entrepreneurial Learning, Entrepreneurship Theory \& Practice, 253 , 5-16.

Nielsen, K. and S.D. Sarasvathy 2011 Who reenters entrepreneurship? And who ought to? An empirical study of success after failure, Paper presented at the DIME-DRUID ACADEMY Winter Conference 2011, Denmark, January 20 - 22.

Ostgaard, T. A., and Birley, S. 1994. Personal Networks and Firm Competitive Strategy - a Strategic or Coincidental Match. Journal of Business Venturing, 94 , 281-305.

Parker, S.C. 2012. Do serial entrepreneurs run successively better-performing businesses? Journal of Business Venturing, http://dx.doi.org/10.1016/j.jbusvent.2012.08.001

Parker, S.C. 2009. The Economics of Self-employment and Entrepreneurship, Cambridge University Press, Cambridge.

Parker, S. C. 2006. Learning about the unknown: How fast do entrepreneurs adjust their beliefs? Journal of Business Venturing, 21 1, 1-26.

Plehn-Dujowich, J. 2010. A theory of serial entrepreneurship. Small Business Economics 354 , 377-398.

Politis, D. 2005. The Process of Entrepreneurial Learning: A Conceptual Framework. Entrepreneurship Theory and Practice, 29:4, 399-424.

Politis, D., and Gabrielsson, J. 2009 Entrepreneurs' attitudes towards failure. International Journal of Entrepreneurial Behaviour \& Research, 15:4, 364-383.

Rocha, V. Carneiro, A. and C. A. Varum 2013 Serial entrepreneurship, learning by doing and self-selection, cef.up working paper 2013-12.

Rosenzweig, P. 2007.Misunderstanding the nature of company performance: The halo effect and other business delusions. California Management Review; 49:6-20. 
Santarelli, E and M. Vivarelli 2007. Entrepreneurship and the Process of Firms' Entry, Survival and Growth. Industrial and Corporate Change 16: 455-488.

Schmidt, F.L., Hunter, J., 2004. General mental ability in the world of work: occupational attainment and job performance. Journal of Personality \& Social Psychology 86, 162-173.

Shane, S. and Venkataraman, S. 2000. The promise of entrepreneurship as a field of research. Academy of Management Review, 25 1 , 217-226.

Shane, S., Locke, E.A. and Collins, C.J. 2003. Entrepreneurial motivation, Human Resource Management Review, 132 , 257-279.

Shepherd, D. A. 2003. Learning from business failure: Propositions of grief recovery for the self-employed. Academy of Management Review, 282 , 318-328.

Sitkin, S.B. 1992 , Learning Through Failure: The Strategy of Small Losses. In: Shaw, B.M., Cummings, L.L. Eds. , Research in Organisational Behaviour, 14, 231-266.

Smilor, R.W. 1997. Entrepreneurship: Reflections on a Subversive Activity, Journal of Business Venturing, 125 , 341-346.

Stam, E. and Schutjens, V.A.J.M, 2005. 'The Fragile Success of Team Start ups', Papers on Entrepreneurship. Growth and Public Policy, Paper 1705, Max Planck Institute, Jena.

Stinchcombe, A.L. 1965. 'Social structure and organizations.' In J.G. March, ed., Handbook of Organizations. Chicago: Rand McNally Publishers: 142-193.

Storey, D.J. and Greene, F.J. 2010. Small Business and Entrepreneurship, London: Pearson/FT.

Stuart, R. W. and Abetti, P. A. 1990. Impact of entrepreneurial and management experience on early performance. Journal of Business Venturing, 53 , 151-162.

Sueyoshi, G. 1995. A Class of Binary Response Models for Grouped Duration Data. Journal of Applied Econometrics, 104 , 411-431.

Taylor, M. P. 1999. Survival of the fittest? An analysis of self-employment duration in Britain. Economic Journal, 109454 , C140-C155.

Thompson, P. 2009. 'Learning by doing,' in B. Hall and N. Rosenberg eds , Handbook of Economics of Technological Change. Elsevier/North-Holland: The Netherlands.

Toft-Kehler, R., Wennberg, K. and P.H. Kim 2013. Practice Makes Perfect: Entrepreneurial-

Experience Curves and Venture Performance, Journal of Business Venturing.

Ucbasaran, D., Westhead, P. and Wright, M. 2006 Habitual Entrepreneurs. Aldershot: Edward Elgar.

Ucbasaran, D., Westhead, P., Wright, M. and Flores, M. 2010. The nature of entrepreneurial experience, business failure and comparative optimism. Journal of Business Venturing, 25, 541-555.

Ucbasaran, D., Shepherd, D.A., Lockett, A. and Lyon, J. 2013. Life after Business Failure: The Process and Consequences of Business Failure for Entrepreneurs, Journal of Management.

van Praag, C.M. 2003. Business Survival and Success of Young Small business Owners, Small Business Economics, 21 1 , 1-17.

Vaillant, Y. and Lafuente, E. 2007. Do Different Institutional Frameworks Condition the Influence of Local Fear of Failure and Entrepreneurial Examples over Entrepreneurial Activity?, Entrepreneurship and Regional Development, 19: 313-337.

Watson, J., and Everett, J. E. 1996. Do small businesses have high failure rates: Evidence from Australian retailers. Journal of Small Business Management, 34 , 45-62.

Weiner B (1974) Achievement Motivation and Attribution Theory, General Learning Press, Morristown, NJ.

Wennberg, K., Wiklund, J., DeTienne, D. R., and Cardon, M. S. 2010. Reconceptualizing entrepreneurial exit: Divergent exit routes and their drivers. Journal of Business Venturing, 25 $4,361-375$. 
Wennberg, K. and DeTienne, D. R.. forthcoming. What do we really mean when we talk about 'Exit'? -A Critical Review of Research on Entrepreneurial Exit, International Small Business Journal.

Westhead, P. and Wright, M. 2011. David Storey's optimism and chance perspective: A case of the Emperor's new clothes? International Small Business Journal, 296 , 714-729.

Westhead, P. and Wright, M. 1998. Novice, Serial and Portfolio Founders: Are They Different?, Journal of Business Venturing, 133 , 173-204.

Westhead, P., Ucbasaran, D. and Wright, M. 2003. Differences between private firms owned by novice, serial and portfolio entrepreneurs: implications for policymakers and practitioners. Regional Studies 37, 187-200.

Wright, M., Robbie, K., and Ennew, C., 1997. Serial entrepreneurs. British Journal of Management 8, 251-268.

Wooldridge, J. 2002. Econometric Analysis of Cross Section and Panel Data. Cambridge, MA, London: The MIT Press. 
Table 1: Summary Statistics and T-Tests

\begin{tabular}{|c|c|c|c|c|c|c|c|c|c|c|c|c|c|c|c|c|}
\hline \multirow{2}{*}{$\begin{array}{l}\text { VARIABLE } \\
\text { Dependent variables }\end{array}$} & \multicolumn{2}{|l|}{ All } & \multicolumn{3}{|c|}{ Portfolio } & \multicolumn{3}{|l|}{ Serial } & \multicolumn{3}{|l|}{ Failed } & \multicolumn{3}{|l|}{ Mixed } & \multicolumn{2}{|l|}{ Novice } \\
\hline & Mean & Std. Dev & Mean & $\begin{array}{l}\text { Std. } \\
\text { Dev }\end{array}$ & T-test sig. & Mean & Std. Dev & T-test sig. & Mean & Std. Dev & T-test sig. & Mean & Std. Dev & T-test sig. & Mean & Std. Dev \\
\hline Survival & 0.892 & 0.311 & 0.899 & 0.301 & & 0.89 & 0.313 & & 0.856 & 0.352 & $* * *$ & 0.872 & 0.336 & & 0.896 & 0.305 \\
\hline Bankruptcy & 0.04 & 0.197 & 0.04 & 0.195 & & 0.043 & 0.202 & & 0.065 & 0.247 & $* *$ & 0.083 & 0.277 & $* *$ & 0.036 & 0.187 \\
\hline \multicolumn{17}{|c|}{ Prior entrepreneurial experience } \\
\hline PORTFOLIO & 0.09 & 0.287 & & & & & & & & & & & & & & \\
\hline SERIALS & 0.059 & 0.235 & & & & & & & & & & & & & & \\
\hline FAILURE & 0.107 & 0.309 & & & & & & & & & & & & & & \\
\hline MIX_EXP & 0.013 & 0.113 & & & & & & & & & & & & & & \\
\hline \multicolumn{17}{|c|}{ Entrepreneurial characteristics } \\
\hline FEMALE & 0.143 & 0.35 & 0.108 & 0.311 & $* * *$ & 0.089 & 0.286 & $* * *$ & 0.109 & 0.311 & $* * *$ & 0.083 & 0.277 & ** & 0.157 & 0.364 \\
\hline DEGREE & 0.306 & 0.461 & 0.47 & 0.499 & $* * *$ & 0.413 & 0.493 & $* * *$ & 0.344 & 0.475 & $* * *$ & 0.404 & 0.493 & $* *$ & 0.27 & 0.444 \\
\hline MASTERCRAFT & 0.294 & 0.456 & 0.212 & 0.409 & $* * *$ & 0.22 & 0.414 & $* * *$ & 0.235 & 0.424 & $* * *$ & 0.165 & 0.373 & $* *$ & 0.321 & 0.467 \\
\hline AGE in years & 40.897 & 9.846 & 43.352 & 9.069 & $* * *$ & 47.203 & 10.042 & $* * *$ & 43.557 & 9.613 & $* * *$ & 44.917 & 9.289 & $* * *$ & 39.627 & 9.617 \\
\hline IND_EXP in years & 15.461 & 9.68 & 15.444 & 10.295 & $*$ & 19.467 & 11.113 & $* * *$ & 16.862 & 10.216 & $* * *$ & 16.138 & 9.618 & & 14.925 & 9.298 \\
\hline MANAGE_EXP & 0.373 & 0.484 & 0.234 & 0.424 & $* * *$ & 0.309 & 0.463 & $* * *$ & 0.302 & 0.46 & $* * *$ & 0.248 & 0.434 & ** & 0.407 & 0.491 \\
\hline OPPORTUNITY & 0.27 & 0.444 & 0.421 & 0.494 & $* * *$ & 0.331 & 0.471 & $* * *$ & 0.269 & 0.444 & $*$ & 0.459 & 0.501 & $* * *$ & 0.243 & 0.429 \\
\hline NECESSITY & 0.192 & 0.394 & 0.091 & 0.288 & $* * *$ & 0.126 & 0.332 & $* * *$ & 0.193 & 0.395 & & 0.128 & 0.336 & $* *$ & 0.211 & 0.408 \\
\hline \multicolumn{17}{|l|}{ Venture characteristics } \\
\hline SIZE & 3.369 & 5.585 & 4.09 & 5.546 & $* * *$ & 4.701 & 12.54 & $* * *$ & 3.01 & 4.466 & & 3.75 & 4.059 & & 3.219 & 4.775 \\
\hline LTD & 0.267 & 0.443 & 0.614 & 0.487 & $* * *$ & 0.465 & 0.499 & $* * *$ & 0.31 & 0.463 & $* * *$ & 0.541 & 0.501 & $* * *$ & 0.198 & 0.398 \\
\hline $\mathrm{R} \& \mathrm{D}$ & 0.176 & 0.381 & 0.299 & 0.458 & $* * *$ & 0.276 & 0.448 & $* * *$ & 0.222 & 0.416 & $* * *$ & 0.294 & 0.458 & $* * *$ & 0.144 & 0.351 \\
\hline \multicolumn{17}{|l|}{ Financial controls } \\
\hline INV ( $€$ thousands) & 35.345 & 305.778 & 69.486 & 350.24 & $* * *$ & 101.377 & 1135.58 & $* * *$ & 25.379 & 78.76 & & 35.862 & 79.063 & & 27.265 & 87.723 \\
\hline INV DUM & 0.253 & 0.435 & 0.238 & 0.426 & & 0.24 & 0.427 & & 0.275 & 0.447 & & 0.193 & 0.396 & & 0.254 & 0.435 \\
\hline RETAINED & 65.742 & 41.031 & 63.88 & 41.686 & $*$ & 62.947 & 42.368 & $* *$ & 65.626 & 41.045 & & 61.348 & 42.013 & & 66.292 & 40.814 \\
\hline EXTERNAL & 12.586 & 27.658 & 10.709 & 25.528 & $* *$ & 11.665 & 26.343 & & 11.066 & 25.208 & $* *$ & 17.183 & 32.215 & $* *$ & 13.032 & 28.245 \\
\hline PUBLIC & 0.336 & 0.473 & 0.249 & 0.433 & $* * *$ & 0.226 & 0.418 & $* * *$ & 0.251 & 0.434 & $* * *$ & 0.275 & 0.449 & $* *$ & 0.37 & 0.483 \\
\hline FIN_PROBLEMS & 0.156 & 0.363 & 0.181 & 0.385 & $* *$ & 0.175 & 0.38 & $*$ & 0.214 & 0.41 & $* * *$ & 0.266 & 0.444 & $* * *$ & 0.141 & 0.349 \\
\hline \multicolumn{17}{|l|}{ Sector } \\
\hline CET & 0.058 & 0.235 & 0.063 & 0.244 & & 0.067 & 0.25 & & 0.055 & 0.228 & & 0.083 & 0.277 & & 0.057 & 0.232 \\
\hline HT & 0.035 & 0.184 & 0.06 & 0.237 & $* * *$ & 0.047 & 0.211 & $* *$ & 0.038 & 0.191 & & 0.037 & 0.189 & & 0.031 & 0.172 \\
\hline NTB_SERVICES & 0.197 & 0.398 & 0.197 & 0.398 & & 0.27 & 0.445 & $* * *$ & 0.24 & 0.427 & $* * *$ & 0.239 & 0.428 & & 0.184 & 0.387 \\
\hline SOFTWARE & 0.06 & 0.238 & 0.086 & 0.281 & $* * *$ & 0.081 & 0.274 & $* *$ & 0.095 & 0.294 & $* * *$ & 0.101 & 0.303 & $* *$ & 0.049 & 0.217 \\
\hline OTHER_MANU & 0.114 & 0.317 & 0.11 & 0.313 & & 0.1 & 0.3 & & 0.091 & 0.287 & $* *$ & 0.083 & 0.277 & & 0.119 & 0.324 \\
\hline KNOW_SERVICES & 0.055 & 0.229 & 0.065 & 0.246 & * & 0.081 & 0.274 & $* *$ & 0.067 & 0.25 & $* *$ & 0.11 & 0.314 & $* *$ & 0.049 & 0.217 \\
\hline OTHER_SERVICES & 0.057 & 0.232 & 0.053 & 0.224 & & 0.069 & 0.254 & & 0.056 & 0.23 & & 0.055 & 0.229 & & 0.057 & 0.231 \\
\hline
\end{tabular}




\begin{tabular}{|c|c|c|c|c|c|c|c|c|c|c|c|c|c|c|c|c|}
\hline CONSUME_SERVICES & 0.132 & 0.338 & 0.138 & 0.345 & & 0.128 & 0.334 & & 0.133 & 0.34 & & 0.092 & 0.29 & & 0.132 & 0.338 \\
\hline CONSTRUCTION & 0.129 & 0.335 & 0.085 & 0.279 & $* * *$ & 0.041 & 0.198 & $* * *$ & 0.096 & 0.295 & $* * *$ & 0.055 & 0.229 & ** & 0.147 & 0.354 \\
\hline RETAIL & 0.164 & 0.37 & 0.144 & 0.352 & $*$ & 0.116 & 0.32 & $* *$ & 0.129 & 0.335 & $* *$ & 0.147 & 0.356 & & 0.175 & 0.38 \\
\hline \multicolumn{17}{|l|}{ Year of firm foundation } \\
\hline 2005 & 0.133 & 0.339 & 0.089 & 0.284 & $* * *$ & 0.096 & 0.294 & ** & 0.157 & 0.364 & & 0.083 & 0.277 & $*$ & 0.138 & 0.345 \\
\hline 2006 & 0.163 & 0.369 & 0.112 & 0.316 & $* * *$ & 0.152 & 0.36 & & 0.17 & 0.376 & & 0.092 & 0.29 & $* *$ & 0.17 & 0.376 \\
\hline 2007 & 0.18 & 0.384 & 0.198 & 0.399 & & 0.177 & 0.382 & & 0.169 & 0.375 & & 0.101 & 0.303 & ** & 0.181 & 0.385 \\
\hline 2008 & 0.14 & 0.347 & 0.14 & 0.347 & & 0.165 & 0.371 & & 0.137 & 0.344 & & 0.119 & 0.326 & & 0.139 & 0.346 \\
\hline 2009 & 0.152 & 0.359 & 0.19 & 0.393 & ** & 0.15 & 0.358 & & 0.143 & 0.351 & & 0.229 & 0.422 & ** & 0.147 & 0.354 \\
\hline 2010 & 0.133 & 0.339 & 0.153 & 0.361 & $*$ & 0.128 & 0.334 & & 0.131 & 0.338 & & 0.22 & 0.416 & ** & 0.129 & 0.335 \\
\hline 2011 & 0.1 & 0.3 & 0.116 & 0.321 & $*$ & 0.132 & 0.339 & $* *$ & 0.093 & 0.291 & & 0.156 & 0.364 & $* *$ & 0.096 & 0.294 \\
\hline
\end{tabular}

The values for the time-varying characteristics refer to the last reporting year.

***, **, * depict significance at the $1 \%, 5 \%$ and $10 \%$ level respectively and corresponds to the T-Test of the difference to the mean value of novice entrepreneurs being zero. 
Table 2: Correlation matrix

\begin{tabular}{|c|c|c|c|c|c|c|c|c|c|c|c|c|c|c|}
\hline & 1 & 2 & 3 & 4 & 5 & 6 & 7 & 8 & 9 & 10 & 11 & 12 & 13 & 14 \\
\hline 1 SURVIVAL & 1 & & & & & & & & & & & & & \\
\hline 2 PORTFOLIO & 0.008 & 1 & & & & & & & & & & & & \\
\hline 3 SERIAL & -0.001 & -0.079 & 1 & & & & & & & & & & & \\
\hline 4 FAILURE & -0.040 & -0.109 & -0.086 & 1 & & & & & & & & & & \\
\hline 5 MIX_EXP & -0.007 & -0.036 & -0.029 & -0.040 & 1 & & & & & & & & & \\
\hline 6 FEMALE & -0.015 & -0.031 & -0.038 & -0.034 & -0.020 & 1 & & & & & & & & \\
\hline 7 DEGREE & -0.003 & 0.112 & 0.058 & 0.029 & 0.024 & -0.043 & 1 & & & & & & & \\
\hline 8 MASTERCRAFT & 0.049 & -0.057 & -0.041 & -0.045 & -0.033 & -0.072 & -0.428 & 1 & & & & & & \\
\hline 9 AGE & 0.004 & 0.079 & 0.160 & 0.093 & 0.047 & 0.019 & 0.192 & -0.061 & 1 & & & & & \\
\hline 10 IND_EXP & 0.055 & -0.001 & 0.103 & 0.050 & 0.008 & -0.118 & -0.031 & 0.170 & 0.564 & 1 & & & & \\
\hline 11 MANAGE_EXP & 0.009 & -0.090 & -0.033 & -0.050 & -0.030 & -0.057 & 0.090 & 0.063 & 0.105 & 0.147 & 1 & & & \\
\hline 12 OPPORTUNIY & -0.012 & 0.107 & 0.035 & -0.001 & 0.049 & 0.003 & 0.103 & -0.063 & 0.012 & -0.078 & 0.022 & 1 & & \\
\hline 13 NECESSITY & -0.031 & -0.081 & -0.042 & 0.000 & -0.019 & 0.013 & -0.076 & 0.018 & 0.131 & 0.089 & -0.044 & -0.296 & 1 & \\
\hline 14 SIZE & -0.014 & 0.041 & 0.060 & -0.022 & 0.008 & -0.021 & 0.047 & 0.020 & 0.051 & 0.057 & 0.109 & 0.058 & -0.067 & 1 \\
\hline 15 LTD & 0.027 & 0.247 & 0.112 & 0.033 & 0.071 & -0.098 & 0.307 & -0.138 & 0.182 & 0.048 & 0.068 & 0.178 & -0.115 & 0.211 \\
\hline $16 \mathrm{R} \& \mathrm{D}$ & -0.023 & 0.102 & 0.066 & 0.041 & 0.035 & -0.088 & 0.202 & -0.096 & 0.047 & 0.004 & 0.047 & 0.185 & -0.077 & 0.058 \\
\hline 17 INV (€ 000s) & 0.003 & 0.035 & 0.054 & -0.011 & 0.000 & -0.017 & 0.025 & -0.003 & 0.031 & 0.030 & 0.008 & 0.013 & -0.024 & 0.272 \\
\hline 18 RETAINED & 0.123 & -0.014 & -0.017 & -0.001 & -0.012 & -0.061 & 0.027 & 0.027 & 0.089 & 0.143 & 0.044 & -0.045 & 0.008 & 0.064 \\
\hline 19 EXTERNAL & 0.009 & -0.021 & -0.008 & -0.019 & 0.019 & 0.022 & -0.036 & 0.045 & -0.055 & -0.043 & 0.027 & 0.024 & -0.017 & 0.065 \\
\hline 20 PUBLIC & -0.004 & -0.059 & -0.059 & -0.063 & -0.015 & 0.030 & -0.052 & 0.072 & -0.112 & -0.067 & 0.046 & -0.014 & 0.038 & 0.076 \\
\hline 21 FIN_PROBLEM & -0.128 & 0.022 & 0.013 & 0.055 & 0.035 & 0.006 & -0.014 & -0.028 & 0.011 & -0.029 & -0.009 & 0.051 & 0.027 & 0.039 \\
\hline 22 SECTOR & -0.022 & -0.040 & -0.068 & -0.048 & -0.027 & 0.149 & -0.223 & 0.024 & -0.103 & -0.084 & -0.070 & -0.056 & 0.038 & -0.004 \\
\hline 23 FOUND_YEAR & 0.159 & 0.057 & 0.029 & -0.020 & 0.048 & 0.016 & 0.020 & -0.007 & -0.046 & -0.091 & 0.028 & 0.038 & -0.007 & -0.051 \\
\hline
\end{tabular}


Table 2: Correlation matrix

\begin{tabular}{|l|r|r|r|r|r|r|r|r|}
\hline & 15 & 16 & 17 & 18 & 19 & 20 & 21 & 22 \\
\hline 15 LTD & 1 & & & & & & & \\
\hline 16 R\&D & 0.281 & 1 & & & & & & \\
\hline 17 INV $(€ 000 s)$ & 0.066 & 0.050 & 1 & & & & & \\
\hline 18 RETAINED & 0.010 & -0.040 & -0.032 & 1 & & & & \\
\hline 19 EXTERNAL & -0.006 & -0.013 & 0.056 & -0.217 & 1 & & & \\
\hline 20 PUBLIC & -0.052 & 0.005 & 0.043 & -0.184 & 0.231 & 1 & & \\
\hline 21 FIN_PROBLEM & 0.048 & 0.063 & 0.009 & -0.102 & 0.091 & 0.043 & 1 & \\
\hline 22 SECTOR & -0.223 & -0.271 & -0.011 & -0.043 & 0.083 & 0.048 & 0.014 & 1 \\
\hline 23 FOUND_YEAR & 0.162 & 0.010 & 0.017 & 0.031 & 0.137 & 0.219 & 0.013 & 0.006 \\
\hline
\end{tabular}


Table 3 Effect of entrepreneurial experience on new venture survival: Discrete time duration model - random-effects complementary log-log model

\begin{tabular}{|c|c|c|c|c|}
\hline & \multicolumn{2}{|c|}{ Model 1 (Base) } & \multicolumn{2}{|c|}{$\begin{array}{l}\text { Model } 2 \text { (Interaction } \\
\text { terms) }\end{array}$} \\
\hline & Coeff. & Std. error & Coeff. & Std. error \\
\hline \multicolumn{5}{|c|}{ Prior entrepreneurial experience } \\
\hline PORTFOLIO & -0.0154 & $(0.0445)$ & -0.0831 & $(0.146)$ \\
\hline SERIALS & -0.0206 & $(0.0520)$ & -0.0133 & $(0.197)$ \\
\hline FAILURE & $-0.0969 * * *$ & $(0.0364)$ & -0.129 & $(0.138)$ \\
\hline MIX_EXP & -0.173 & $(0.106)$ & -0.310 & $(0.384)$ \\
\hline PORTFOLIO*DEGREE & & & -0.0102 & $(0.0853)$ \\
\hline $\begin{array}{l}\text { SERIALS*DEGREE } \\
\end{array}$ & & & 0.0335 & $(0.102)$ \\
\hline FAILURE*DEGREE & & & $0.165 * *$ & $(0.0773)$ \\
\hline MIX_EXP*DEGREE & & & 0.192 & $(0.233)$ \\
\hline PORTFOLIO*IND_EXP & & & 0.0613 & $\overline{(0.0461)}$ \\
\hline $\begin{array}{l}\text { SERIALS*IND_EXP } \\
\end{array}$ & & & 0.0287 & $(0.0597)$ \\
\hline FAILURE*IND_EXP & & & -0.0161 & $(0.0456)$ \\
\hline MIX_EXP*IND_EXP & & & 0.104 & $(0.121)$ \\
\hline PORTFOLIO*INV & & & -0.00879 & $(0.00975)$ \\
\hline SERIALS*INV & & & -0.0121 & $(0.0113)$ \\
\hline FAILURE*INV & & & 0.00325 & $(0.00811)$ \\
\hline MIX_EXP*INV & & & -0.0229 & $(0.0265)$ \\
\hline \multicolumn{5}{|c|}{ Entrepreneurial characteristics } \\
\hline FEMALE & -0.0176 & $(0.0346)$ & -0.0175 & $(0.0346)$ \\
\hline DEGREE & 0.0319 & $(0.0298)$ & 0.00571 & $(0.0346)$ \\
\hline MASTERCRAFT & $0.0956 * * *$ & $(0.0300)$ & $0.0979 * * *$ & $(0.0301)$ \\
\hline AGE & $3.652 * * *$ & $(1.100)$ & $3.845 * * *$ & $(1.110)$ \\
\hline AGE2 & $-0.508 * * *$ & $(0.150)$ & $-0.534 * * *$ & $(0.152)$ \\
\hline IND_EXP & $0.0803 * * *$ & $(0.0167)$ & $0.0700 * * *$ & $(0.0195)$ \\
\hline MANAGE_EXP & -0.0258 & $(0.0253)$ & -0.0242 & $(0.0255)$ \\
\hline OPPORTUNITY & -0.0321 & $(0.0280)$ & -0.0299 & $(0.0281)$ \\
\hline NECESSITY & $-0.0882 * * *$ & $(0.0309)$ & -0.0888 & $\overline{(0.0310)}$ \\
\hline \multicolumn{5}{|l|}{ Venture characteristics } \\
\hline SIZE & -0.0505 & $(0.0363)$ & -0.0536 & $(0.0364)$ \\
\hline SIZE2 & -0.0123 & $(0.0133)$ & -0.0114 & $(0.0133)$ \\
\hline LTD & 0.0509 & $(0.0320)$ & $0.0540 *$ & $\overline{(0.0321)}$ \\
\hline $\mathrm{R} \& \mathrm{D}$ & -0.0214 & $(0.0327)$ & -0.0217 & $(0.0328)$ \\
\hline \multicolumn{5}{|l|}{ Financial controls } \\
\hline INV & $0.0353 * * *$ & $(0.0106)$ & $0.0379 * * *$ & $(0.0108)$ \\
\hline INV DUM & $0.219 * *$ & $0.102)$ & $0.232 * *$ & $(0.102)$ \\
\hline RETAINED & $0.00143 * * *$ & & $0.00143 * * *$ & $(0.000408)$ \\
\hline EXTERNAL & 0.000273 & $(0.000470$ & 0.000273 & $(0.000472)$ \\
\hline PUBLIC & 0.0521 & $(0.0272)$ & $0.0501 *$ & $(0.0273)$ \\
\hline FIN_PROBLEMS & $-0.289 * * *$ & $(0.0296)$ & $-0.289 * * *$ & $(0.0297)$ \\
\hline \multicolumn{5}{|l|}{ Other controls } \\
\hline HT & $-0.237 * * *$ & $(0.0817)$ & $-0.242 * * *$ & $(0.0819)$ \\
\hline NTB_SERVICES & $-0.121 *$ & $(0.0619)$ & $-0.120 *$ & $(0.0621)$ \\
\hline SOFTWARE & $-0.195 * * *$ & $(0.0728)$ & $-0.198 * * *$ & $(0.0731)$ \\
\hline OTHER_MANU & $-0.155 * *$ & $(0.0646)$ & $-0.158 * *$ & $(0.0648)$ \\
\hline KNOW_SERVICES & $-0.148 * *$ & $(0.0736)$ & $-0.148 * *$ & $(0.0739)$ \\
\hline
\end{tabular}




\begin{tabular}{|l|r|r|r|r|}
\hline & \multicolumn{2}{|l|}{ Model 1 (Base) } & \multicolumn{2}{l|}{$\begin{array}{l}\text { Model } 2 \text { (Interaction } \\
\text { terms) }\end{array}$} \\
\hline & \multicolumn{1}{|l|}{ Coeff. } & \multicolumn{1}{l|}{ Std. error } & \multicolumn{1}{l|}{ Coeff. } & \multicolumn{1}{l|}{ Std. error } \\
\hline OTHER_SERVICES & $-0.248^{* * *}$ & $(0.0736)$ & $-0.248 * * *$ & $(0.0738)$ \\
\hline CONSUME_SERVICES & $-0.197 * * *$ & $(0.0645)$ & $-0.203^{* * *}$ & $(0.0647)$ \\
\hline CONSTRUCTION & $-0.170^{* * *}$ & $(0.0649)$ & $-0.171^{* * *}$ & $(0.0651)$ \\
\hline RETAIL & $-0.136^{* *}$ & $(0.0637)$ & $-0.141^{* *}$ & $(0.0639)$ \\
\hline Found. year 2006 & -0.0548 & $(0.0365)$ & -0.0550 & $(0.0366)$ \\
\hline Found. year 2007 & -0.0313 & $(0.0370)$ & -0.0332 & $(0.0371)$ \\
\hline Found. year 2008 & 0.00861 & $(0.0440)$ & 0.00593 & $(0.0442)$ \\
\hline Found. year 2009 & 0.0169 & $(0.0489)$ & 0.0135 & $(0.0491)$ \\
\hline Found. year 2010 & $0.1000 *$ & $(0.0597)$ & 0.0971 & $(0.0600)$ \\
\hline Found. year 2011 & $0.215^{* *}$ & $(0.0856)$ & $0.219 * *$ & $(0.0862)$ \\
\hline Reporting year 2007 & $-0.167 * * *$ & $(0.0583)$ & $-0.171 * * *$ & $(0.0585)$ \\
\hline Reporting year 2008 & $-0.173 * * *$ & $(0.0439)$ & $-0.175 * * *$ & $(0.0440)$ \\
\hline Reporting year 2009 & $-0.123^{* * *}$ & $(0.0409)$ & $-0.124 * * *$ & $(0.0410)$ \\
\hline Reporting year 2010 & $-0.0684 *$ & $(0.0397)$ & $-0.0674 *$ & $(0.0398)$ \\
\hline Constant & $-5.676 * * *$ & $(2.004)$ & $-6.025 * * *$ & $(2.021)$ \\
\hline Number of Observations & 17,470 & & 17,470 & \\
\hline Number of firms & 8,371 & & 8,371 & \\
\hline WALD chi2(43) & $374.33^{* * *}$ & & & \\
\hline WALD chi2(55) & & & $383.18^{* * *}$ & \\
\hline
\end{tabular}

For Tables $3-6,{ }^{* *}, * *, *$ depict significance at the $1 \%, 5 \%$ and $10 \%$ level respectively and correspond to the test of the underlying coefficient being zero. Reference categories, resp.: formal education: apprenticeship and minor formal education, motive for foundation: self-determination, industry sectors: NTB MANU (CET), foundations year: 2005, reporting year: 2011. 
Table 4 Effect of entrepreneurial experience on new venture survival: Discrete time duration model - random-effects complementary log-log model (restricted samples)

\begin{tabular}{|c|c|c|c|c|}
\hline & \multicolumn{2}{|c|}{$\begin{array}{l}\text { Restricted sample: Entre- } \\
\text { preneurial experi- } \\
\text { ence=FAILURE }\end{array}$} & \multicolumn{2}{|c|}{$\begin{array}{l}\text { Restricted sample: High- } \\
\text { tech-Firms }\end{array}$} \\
\hline & Coeff. & Std. error & Coeff. & Std. error \\
\hline \multicolumn{5}{|c|}{ Prior entrepreneurial experience } \\
\hline PORTFOLIO & & & 0.00821 & $(0.0739)$ \\
\hline SERIALS & & & 0.0339 & $(0.0839)$ \\
\hline FAILURE & & & -0.0811 & $(0.0596)$ \\
\hline MIX_EXP & & & -0.215 & $(0.163)$ \\
\hline \multicolumn{5}{|c|}{ Entrepreneurial characteristics } \\
\hline FEMALE & $-0.294^{* *}$ & $(0.116)$ & -0.0237 & $(0.0785)$ \\
\hline DEGREE & 0.115 & $(0.0879)$ & -0.0218 & $(0.0504)$ \\
\hline MASTERCRAFT & 0.0519 & $(0.0929)$ & 0.0421 & $(0.0590)$ \\
\hline AGE & $10.99 * * *$ & $(3.845)$ & $6.168 * * *$ & $(1.830)$ \\
\hline AGE2 & $-1.491 * * *$ & $(0.516)$ & $-0.855^{* * *}$ & $(0.249)$ \\
\hline IND_EXP & 0.0268 & $(0.0540)$ & $0.116^{* * *}$ & $(0.0340)$ \\
\hline MANAGE_EXP & $-0.157 * *$ & $(0.0772)$ & -0.0154 & $(0.0441)$ \\
\hline OPPORTUNITY & $-0.234 * * *$ & $(0.0837)$ & $-0.0854 *$ & $(0.0476)$ \\
\hline NECESSITY & -0.110 & $(0.0934)$ & -0.0611 & $(0.0558)$ \\
\hline \multicolumn{5}{|l|}{ Venture characteristics } \\
\hline SIZE & 0.0116 & $(0.116)$ & 0.0453 & $(0.0676)$ \\
\hline SIZE2 & -0.0430 & $(0.0465)$ & -0.0217 & $(0.0257)$ \\
\hline LTD & 0.123 & $(0.0899)$ & 0.0764 & $(0.0516)$ \\
\hline $\mathrm{R} \& \mathrm{D}$ & -0.0562 & $(0.0923)$ & 0.0117 & $(0.0473)$ \\
\hline \multicolumn{5}{|l|}{ Financial controls } \\
\hline INV & 0.0435 & $(0.0332)$ & 0.00284 & $(0.0188)$ \\
\hline INV DUM & 0.234 & $(0.318)$ & -0.0616 & $(0.180)$ \\
\hline RETAINED & 0.00172 & $(0.00127)$ & $0.00157^{* *}$ & $(0.000714)$ \\
\hline EXTERNAL & -0.000714 & $(0.00146)$ & $1.45 \mathrm{e}-05$ & $(0.000938)$ \\
\hline PUBLIC & 0.0346 & $(0.0826)$ & 0.0518 & $(0.0478)$ \\
\hline FIN_PROBLEMS & $-0.196^{* *}$ & $(0.0833)$ & $-0.272 * * *$ & $(0.0532)$ \\
\hline \multicolumn{5}{|l|}{ Other controls } \\
\hline HT & -0.336 & $(0.259)$ & $-0.250 * * *$ & $(0.0835)$ \\
\hline NTB_SERVICES & -0.286 & $(0.185)$ & -0.0907 & $(0.0659)$ \\
\hline SOFTWARE & $-0.428 * *$ & $(0.206)$ & $-0.179 * *$ & $(0.0780)$ \\
\hline OTHER_MANU & -0.286 & $(0.200)$ & & \\
\hline KNOW_SERVICES & 0.0203 & $(0.236)$ & & \\
\hline OTHER_SERVICES & -0.325 & $(0.226)$ & & \\
\hline CONSUME_SERVICES & $-0.349 *$ & $(0.196)$ & & \\
\hline CONSTRUCTION & $-0.483^{* *}$ & $(0.199)$ & & \\
\hline RETAIL & -0.285 & $(0.199)$ & & \\
\hline Found. year 2006 & 0.0187 & $(0.109)$ & -0.0408 & $(0.0612)$ \\
\hline Found. year 2007 & -0.134 & $(0.110)$ & -0.0110 & $(0.0633)$ \\
\hline Found. year 2008 & 0.00855 & $(0.127)$ & 0.0968 & $(0.0760)$ \\
\hline Found. year 2009 & -0.0425 & $(0.140)$ & 0.0470 & $(0.0830)$ \\
\hline Found. year 2010 & $0.478 * *$ & $(0.206)$ & $0.275 * *$ & $(0.107)$ \\
\hline Found. year 2011 & 0.135 & $(0.230)$ & $0.326^{* *}$ & $(0.142)$ \\
\hline Reporting year 2007 & -0.00142 & $(0.170)$ & -0.110 & $(0.0999)$ \\
\hline
\end{tabular}




\begin{tabular}{|l|r|r|r|r|}
\hline & \multicolumn{2}{|l|}{$\begin{array}{l}\text { Restricted sample: Entre- } \\
\text { preneurial experi- } \\
\text { ence=FAILURE }\end{array}$} & \multicolumn{3}{l|}{$\begin{array}{l}\text { Restricted sample: High- } \\
\text { tech-Firms }\end{array}$} \\
\hline & Coeff. & \multicolumn{1}{l|}{$\begin{array}{l}\text { Std. error } \\
\text { Coeff. }\end{array}$} & \multicolumn{1}{l|}{ Std. error } \\
\hline Reporting year 2008 & -0.0537 & $(0.130)$ & -0.0916 & $(0.0743)$ \\
\hline Reporting year 2009 & -0.0981 & $(0.122)$ & -0.0902 & $(0.0695)$ \\
\hline Reporting year 2010 & -0.0709 & $(0.120)$ & -0.0545 & $(0.0684)$ \\
\hline Constant & $-19.17^{* * *}$ & $(7.117)$ & $-10.15^{* * *}$ & $(3.346)$ \\
\hline Number of Observations & 1,886 & & 6,156 & 2,953 \\
\hline Number of firms & 893 & & 2,953 & \\
\hline WALD chi2(35) & $69.45^{* * *}$ & & & \\
\hline WALD chi2(37) & & & $137.05^{* * * *}$ & \\
\hline
\end{tabular}


Table 5 Competing risk model for interval censored data: Multinomial logistic model (Base outcome: Survival)

\begin{tabular}{|c|c|c|c|c|c|c|c|c|}
\hline & \multicolumn{4}{|c|}{ Model 1 (Base) } & \multicolumn{4}{|c|}{ Model 2 (Interaction terms) } \\
\hline & Coeff. & $\begin{array}{l}\text { Std. } \\
\text { error }\end{array}$ & Coeff. & $\begin{array}{l}\begin{array}{l}\text { Std. } \\
\text { error }\end{array} \\
\text { ero }\end{array}$ & Coeff. & $\begin{array}{l}\text { Std. } \\
\text { error }\end{array}$ & Coeff. & $\begin{array}{l}\text { Std. } \\
\text { error }\end{array}$ \\
\hline & \multicolumn{2}{|c|}{$\begin{array}{c}\text { failure event 1: vol- } \\
\text { untary exit }\end{array}$} & \multicolumn{2}{|c|}{$\begin{array}{c}\text { failure event 2: } \\
\text { bankruptcy } \\
\end{array}$} & \multicolumn{2}{|c|}{$\begin{array}{c}\text { failure event 1: vol- } \\
\text { untary exit } \\
\end{array}$} & \multicolumn{2}{|c|}{$\begin{array}{c}\text { failure event 2: } \\
\text { bankruptcy }\end{array}$} \\
\hline \multicolumn{9}{|c|}{ Prior entrepreneurial experience } \\
\hline PORTFOLIO & 0.0611 & $(0.169)$ & 0.0599 & $(0.213)$ & 0.0109 & $(0.515)$ & 0.748 & $(0.625)$ \\
\hline SERIALS & 0.0639 & $(0.194)$ & 0.154 & $(0.244)$ & 0.0204 & $(0.724)$ & 0.279 & $\overline{(0.890)}$ \\
\hline FAILURE & 0.0719 & $(0.136)$ & $0.628 * *$ & $(0.159)$ & -0.124 & $(0.477)$ & $0.956^{*}$ & $(0.546)$ \\
\hline MIX_EXP & -0.0345 & $(0.465)$ & $1.101^{* *}$ & $(0.369)$ & -7.105 & $(4.400)$ & $2.038 *$ & $(1.162)$ \\
\hline $\begin{array}{l}\text { PORTFOLIO } \\
\text { *DEGREE }\end{array}$ & & & & & -0.0672 & $(0.324)$ & 0.159 & $(0.415)$ \\
\hline SERIALS*DEGREE & & & & & -0.398 & $(0.389)$ & 0.281 & $(0.495)$ \\
\hline FAILURE*DEGREE & & & & & $-0.598 * *$ & $(0.293)$ & -0.118 & $(0.361)$ \\
\hline MIX_EXP*DEGREE & & & & & -1.152 & $(1.163)$ & 0.397 & $(0.813)$ \\
\hline $\begin{array}{l}\text { PORTFOLIO } \\
\text { *IND_EXP }^{*}\end{array}$ & & & & & -0.113 & $(0.162)$ & -0.265 & $(0.209)$ \\
\hline SERIALS*IND_EXP & & & & & 0.00364 & $(0.222)$ & -0.178 & $(0.266)$ \\
\hline FAILURE*IND_EXP & & & & & 0.0812 & $(0.161)$ & 0.0140 & $(0.189)$ \\
\hline MIX_EXP*IND_EXP & & & & & -0.305 & $(0.512)$ & -0.370 & $(0.389)$ \\
\hline PORTFOLIO*INV & & & & & 0.0445 & $(0.0377)$ & -0.0205 & $(0.0421)$ \\
\hline PORTFOLIO*INV & & & & & 0.0274 & $(0.0424)$ & 0.0255 & $(0.0532)$ \\
\hline FAILURE*INV & & & & & 0.0293 & $(0.0310)$ & -0.0519 & $(0.0321)$ \\
\hline MIX_EXP*INV & & & & & $0.841^{* *}$ & $(0.422)$ & -0.0237 & $(0.0817)$ \\
\hline \multicolumn{9}{|c|}{ Entrepreneurial characteristics } \\
\hline & & & & & & & & \\
\hline FEMALE & -0.0360 & $(0.130)$ & 0.201 & $(0.156)$ & -0.0287 & $(0.130)$ & 0.206 & $(0.157)$ \\
\hline DEGREE & 0.0505 & $(0.108)$ & - & $(0.150)$ & 0.174 & $(0.124)$ & - & $(0.187)$ \\
\hline MASTERCRAFT & $-0.302^{* *}$ & $(0.120)$ & -0.203 & $(0.143)$ & $-0.302^{* *}$ & $(0.120)$ & -0.220 & $\overline{(0.144)}$ \\
\hline AGE & $-11.22^{* * *}$ & (3.643) & -8.414 & (5.373) & $-11.67^{* * *}$ & (3.671) & -8.791 & $(5.440)$ \\
\hline AGE2 & $1.589^{* * *}$ & $(0.500)$ & 1.131 & $(0.738)$ & $1.647^{* * *}$ & $(0.504)$ & 1.180 & $(0.747)$ \\
\hline IND_EXP & $-0.263^{* * *}$ & $(0.0596)$ & - & $(0.0773)$ & $-0.253^{* * *}$ & $(0.0692)$ & -0.138 & $(0.0948)$ \\
\hline MANAGE_EXP & -0.0438 & $(0.0982)$ & $0.263^{* *}$ & $(0.122)$ & -0.0500 & $(0.0989)$ & $0.256^{* *}$ & $(0.123)$ \\
\hline OPPORTUNITY & 0.0613 & $\begin{array}{l}(0.106) \\
\end{array}$ & 0.141 & $(0.135)$ & 0.0529 & $(0.106)$ & 0.142 & $(0.136)$ \\
\hline NECESSITY & 0.0963 & $(0.115)$ & $0.559 * *$ & $(0.146)$ & 0.0951 & $(0.115)$ & $0.565^{* *}$ & $(0.147)$ \\
\hline \multicolumn{9}{|l|}{ Venture characteristics } \\
\hline$\overline{\text { SIZE }}$ & 0.0338 & $(0.141)$ & $0.533 * *$ & $(0.166)$ & 0.0305 & $(0.141)$ & $0.533 * *$ & $(0.166)$ \\
\hline SIZE2 & 0.0179 & $(0.0550)$ & -0.0434 & $(0.0517)$ & 0.0201 & $(0.0555)$ & -0.0421 & $(0.0519)$ \\
\hline LTD & $-0.543 * * *$ & $(0.134)$ & $0.506 * *$ & $(0.145)$ & $-0.553 * * *$ & $(0.134)$ & $0.505 * *$ & $(0.146)$ \\
\hline $\mathrm{R} \& \mathrm{D}$ & 0.0299 & $(0.121)$ & 0.188 & $(0.155)$ & 0.0329 & $(0.121)$ & 0.189 & $(0.156)$ \\
\hline \multicolumn{9}{|l|}{ Financial controls } \\
\hline INV & $-0.109 * * *$ & $(0.0400)$ & -0.0860 & $(0.0524)$ & $-0.132 * * *$ & $(0.0412)$ & -0.0787 & $(0.0537)$ \\
\hline INV DUM & $-0.742^{* *}$ & $(0.378)$ & -0.422 & $(0.522)$ & $-0.853^{* *}$ & $(0.380)$ & -0.453 & $(0.525)$ \\
\hline RETAINED & - & $(0.00152$ & - & $(0.00191$ & - & $(0.00152$ & - & (0.00191 \\
\hline EXTERNAL & -0.00179 & $(0.00196$ & 0.00055 & $(0.00207$ & -0.00182 & $(0.00196$ & 0.00025 & $(0.00208$ \\
\hline PUBLIC & $-0.195 *$ & $(0.104)$ & -0.0951 & $(0.127)$ & $-0.183^{*}$ & $(0.104)$ & -0.0835 & $(0.128)$ \\
\hline FIN_PROBLEMS & $0.450 * * *$ & $(0.111)$ & $1.316^{* *}$ & $(0.117)$ & $0.447 * * *$ & $(0.111)$ & $1.313^{* *}$ & $(0.118)$ \\
\hline
\end{tabular}




\begin{tabular}{|c|c|c|c|c|c|c|c|c|}
\hline & \multicolumn{4}{|c|}{ Model 1 (Base) } & \multicolumn{4}{|c|}{ Model 2 (Interaction terms) } \\
\hline & Coeff. & $\begin{array}{l}\text { Std. } \\
\text { error }\end{array}$ & Coeff. & $\begin{array}{l}\text { Std. } \\
\text { error }\end{array}$ & Coeff. & $\begin{array}{l}\text { Std. } \\
\text { error }\end{array}$ & Coeff. & $\begin{array}{l}\text { Std. } \\
\text { error }\end{array}$ \\
\hline & \multicolumn{2}{|c|}{$\begin{array}{c}\text { failure event 1: vol- } \\
\text { untary exit }\end{array}$} & \multicolumn{2}{|c|}{$\begin{array}{c}\text { failure event 2: } \\
\text { bankruptcy }\end{array}$} & \multicolumn{2}{|c|}{$\begin{array}{c}\text { failure event 1: vol- } \\
\text { untary exit }\end{array}$} & \multicolumn{2}{|c|}{$\begin{array}{c}\text { failure event 2: } \\
\text { bankruptcy }\end{array}$} \\
\hline \multicolumn{9}{|l|}{ Other control terms } \\
\hline $\mathrm{HT}$ & 0.520 & $(0.344)$ & $0.787 * *$ & $(0.375)$ & 0.537 & $(0.345)$ & $0.804^{* *}$ & $(0.377)$ \\
\hline NTB_SERVICES & $0.440 *$ & $(0.262)$ & -0.0492 & $(0.352)$ & 0.428 & $(0.262)$ & -0.0458 & $(0.352)$ \\
\hline SOFTWARE & $0.679 * *$ & $(0.290)$ & 0.277 & $(0.403)$ & $0.679 * *$ & $(0.290)$ & 0.304 & $(0.405)$ \\
\hline OTHER_MANU & $0.489 *$ & $(0.276)$ & 0.504 & $(0.336)$ & $0.503^{*}$ & $(0.276)$ & 0.512 & $(0.337)$ \\
\hline KNOW_SERVICES & 0.480 & $(0.298)$ & 0.293 & $(0.408)$ & 0.481 & $(0.299)$ & 0.301 & $\overline{(0.409)}$ \\
\hline OTHER_SERVICES & $0.694 * *$ & $\overline{(0.298)}$ & $0.798 * *$ & $(0.367)$ & $0.694 * *$ & $(0.298)$ & $0.791^{* *}$ & $\overline{(0.367)}$ \\
\hline $\begin{array}{l}\text { CON- } \\
\text { SUME_SERVICES }\end{array}$ & 0.450 & $(0.274)$ & $\begin{array}{r}0.876 * * \\
*\end{array}$ & $(0.331)$ & $0.453 *$ & $(0.274)$ & $\begin{array}{r}0.891 * * \\
*\end{array}$ & $(0.332)$ \\
\hline CONSTRUCTION & 0.359 & $(0.280)$ & $0.816^{* *}$ & $(0.337)$ & 0.368 & $(0.281)$ & $0.814^{* *}$ & $(0.338)$ \\
\hline RETAIL & 0.313 & $(0.273)$ & $0.650 * *$ & $(0.331)$ & 0.319 & $(0.273)$ & $0.668 * *$ & $(0.332)$ \\
\hline Found. year 2006 & 0.0170 & $(0.129)$ & $0.406 * *$ & $(0.186)$ & 0.0112 & $(0.129)$ & $0.393 * *$ & $(0.186)$ \\
\hline Found. year 2007 & 0.0250 & $(0.132)$ & 0.301 & $(0.190)$ & 0.0215 & $(0.132)$ & 0.297 & $\begin{array}{l}(0.191) \\
\end{array}$ \\
\hline Found. year 2008 & -0.113 & $(0.167)$ & 0.0759 & $(0.229)$ & -0.116 & $(0.168)$ & 0.0685 & $(0.230)$ \\
\hline Found. year 2009 & -0.186 & $(0.197)$ & 0.203 & $(0.245)$ & -0.187 & (0.198) & 0.190 & $(0.246)$ \\
\hline Found. year 2010 & -0.404 & $(0.257)$ & -0.272 & $(0.314)$ & -0.404 & $(0.258)$ & -0.286 & $(0.315)$ \\
\hline Found. year 2011 & $-1.588 * * *$ & $(0.543)$ & -0.176 & $(0.432)$ & $-1.617 * * *$ & $(0.544)$ & -0.188 & $(0.434)$ \\
\hline Report. year 2007 & $0.525^{* *}$ & $(0.226)$ & 0.424 & $(0.283)$ & $0.516^{* *}$ & $(0.226)$ & 0.438 & (0.283) \\
\hline Report. year 2008 & $0.604 * * *$ & (0.178) & $0.418^{*}$ & $(0.223)$ & $0.601^{* * *}$ & $(0.178)$ & $0.432 *$ & $(0.223)$ \\
\hline Report. year 2009 & $0.444^{* * *}$ & $(0.170)$ & 0.271 & $(0.206)$ & $0.442^{* * *}$ & $(0.170)$ & 0.290 & $(0.206)$ \\
\hline Report. year 2010 & 0.190 & $(0.173)$ & 0.294 & $(0.198)$ & 0.187 & $(0.173)$ & 0.299 & $\overline{(0.199)}$ \\
\hline Constant & $17.69 * * *$ & (6.607) & 10.75 & (9.745) & $18.69 * * *$ & (6.653) & 11.29 & (9.854) \\
\hline Observations & 17,470 & & & & 17,470 & & & \\
\hline LR chi2 (86) & $657.12 * * *$ & & & & & & & \\
\hline LR chi2 (110) & & & & & $680.49 * * *$ & & & \\
\hline
\end{tabular}


Table 6 Competing risk model for interval censored data: Multinomial logistic model (Base outcome: Survival) (restricted samples)

\begin{tabular}{|c|c|c|c|c|c|c|c|c|}
\hline & \multicolumn{4}{|c|}{$\begin{array}{l}\text { Restricted sample: } \\
\text { Entrepreneurial experi- } \\
\text { ence=FAILURE }\end{array}$} & \multicolumn{4}{|c|}{$\begin{array}{l}\text { Restricted sample: } \\
\text { High-tech-Firms }\end{array}$} \\
\hline & Coeff. & $\begin{array}{l}\text { Std. } \\
\text { error }\end{array}$ & Coeff. & $\begin{array}{l}\begin{array}{l}\text { Std. } \\
\text { error }\end{array} \\
\end{array}$ & Coeff. & $\begin{array}{l}\text { Std. } \\
\text { error }\end{array}$ & Coeff. & $\begin{array}{l}\text { Std. } \\
\text { error }\end{array}$ \\
\hline & \multicolumn{2}{|c|}{$\begin{array}{r}\text { failure event 1: } \\
\text { voluntary exit }\end{array}$} & \multicolumn{2}{|c|}{$\begin{array}{c}\text { failure event 2: } \\
\text { bankruptcy }\end{array}$} & \multicolumn{2}{|c|}{$\begin{array}{c}\text { failure event 1: vol- } \\
\text { untary exit }\end{array}$} & \multicolumn{2}{|c|}{$\begin{array}{c}\text { failure event 2: } \\
\text { bankruptcy }\end{array}$} \\
\hline \multicolumn{9}{|c|}{ Prior entrepreneurial experience } \\
\hline PORTFOLIO & & & & & -0.211 & $(0.287)$ & 0.335 & $\overline{(0.393)}$ \\
\hline SERIALS & & & & & -0.227 & $(0.336)$ & 0.210 & $(0.449)$ \\
\hline FAILURE & & & & & 0.0788 & $(0.212)$ & $0.661 * *$ & $(0.329)$ \\
\hline MIX_EXP & & & & & -0.854 & $(1.021)$ & $1.651^{* *}$ & $(0.552)$ \\
\hline \multicolumn{9}{|c|}{ Entrepreneurial characteristics } \\
\hline FEMALE & 0.496 & $(0.391)$ & $0.740^{*}$ & $(0.401)$ & -0.0783 & $(0.285)$ & 0.413 & $\overline{(0.404)}$ \\
\hline DEGREE & -0.433 & $(0.319)$ & -0.134 & $(0.386)$ & $0.301^{*}$ & $(0.179)$ & $-0.561 *$ & $(0.290)$ \\
\hline MASTERCRAFT & -0.352 & $(0.357)$ & 0.216 & $(0.363)$ & -0.0617 & $(0.223)$ & -0.266 & $(0.338)$ \\
\hline AGE & - & $(11.46)$ & -21.29 & $\begin{array}{l}(14.76) \\
\end{array}$ & $-18.39 * * *$ & $(5.470)$ & -7.644 & (11.75) \\
\hline AGE2 & $5.057^{*}$ & $(1.535)$ & 2.748 & $(2.009)$ & $2.558^{* * *}$ & $(0.751)$ & 1.139 & $(1.589)$ \\
\hline IND_EXP & - & $(0.184)$ & -0.0804 & $(0.229)$ & $-0.384 * * *$ & $(0.111)$ & -0.198 & $(0.188)$ \\
\hline MANAGE_EXP & 0.421 & $(0.281)$ & 0.408 & $(0.307)$ & -0.0775 & $(0.161)$ & 0.353 & $(0.258)$ \\
\hline OPPORTUNITY & $0.690 *$ & $(0.286)$ & 0.480 & $(0.349)$ & $0.334 * *$ & $(0.170)$ & - & $(0.271)$ \\
\hline NECESSITY & -0.127 & $(0.367)$ & $1.008^{* *}$ & $(0.364)$ & 0.215 & $(0.196)$ & -0.0100 & $(0.358)$ \\
\hline \multicolumn{9}{|l|}{ Venture characteristics } \\
\hline SIZE & -0.188 & $(0.396)$ & 0.163 & $(0.444)$ & -0.0969 & $(0.285)$ & 0.0309 & $\overline{(0.350)}$ \\
\hline SIZE2 & 0.133 & $(0.152)$ & 0.0291 & $(0.160)$ & -0.0438 & $(0.135)$ & 0.0431 & $(0.114)$ \\
\hline LTD & - & $(0.368)$ & 0.509 & $(0.359)$ & $-0.448 * *$ & (0.199) & $0.512^{*}$ & $(0.291)$ \\
\hline $\mathrm{R} \& \mathrm{D}$ & - & $(0.336)$ & 0.365 & $(0.376)$ & -0.187 & $(0.172)$ & 0.245 & $(0.265)$ \\
\hline \multicolumn{9}{|l|}{ Financial controls } \\
\hline INV & -0.126 & $(0.121)$ & -0.103 & $(0.146)$ & 0.0310 & $(0.0652)$ & 0.0134 & $\overline{(0.113)}$ \\
\hline INV DUM & -1.128 & $(1.148)$ & -0.0384 & (1.439) & 0.375 & $(0.617)$ & 0.751 & (1.139) \\
\hline RETAINED & - & $(0.00425$ & -0.00151 & $(0.00505$ & - & $(0.00261$ & -0.00394 & $(0.00372$ \\
\hline EXTERNAL & - & $(0.00573$ & 0.00379 & $(0.00523$ & -0.00459 & $(0.00398$ & 0.00478 & $(0.00429$ \\
\hline PUBLIC & -0.161 & $(0.316)$ & -0.0791 & $(0.330)$ & -0.227 & $(0.178)$ & 0.0556 & $\overline{(0.260)}$ \\
\hline FIN_PROBLEMS & - & $(0.322)$ & $1.174 * *$ & $(0.298)$ & $0.467 * *$ & $(0.193)$ & $1.306 * *$ & $(0.250)$ \\
\hline \multicolumn{9}{|l|}{ Other controls } \\
\hline HT & -0.196 & $(1.206)$ & 14.89 & $(680.8)$ & 0.497 & $(0.351)$ & $0.802 * *$ & $(0.385)$ \\
\hline NTB_SERVICES & 0.593 & $(0.680)$ & 14.08 & $(680.8)$ & 0.348 & $(0.273)$ & 0.0179 & $(0.370)$ \\
\hline SOFTWARE & $1.196^{*}$ & $(0.718)$ & 14.14 & $(680.8)$ & $0.585 *$ & $(0.307)$ & 0.384 & $(0.433)$ \\
\hline OTHER_MANU & 0.384 & $(0.749)$ & 14.30 & $(680.8)$ & & & & \\
\hline KNOW_SERVICES & -0.556 & $(0.976)$ & 13.60 & $(680.8)$ & & & & \\
\hline OTHER_SERVICES & 0.561 & $(0.829)$ & 14.37 & $(680.8)$ & & & & \\
\hline COSUME_SERVICES & 0.680 & $(0.707)$ & 14.74 & $(680.8)$ & & & & \\
\hline CONSTRUCTION & 0.678 & $(0.766)$ & 15.32 & $(680.8)$ & & & & \\
\hline RETAIL & 0.502 & $(0.722)$ & 14.49 & $(680.8)$ & & & & \\
\hline & & & & & & & & \\
\hline
\end{tabular}




\begin{tabular}{|c|c|c|c|c|c|c|c|c|}
\hline & \multicolumn{4}{|c|}{$\begin{array}{l}\text { Restricted sample: } \\
\text { Entrepreneurial experi- } \\
\text { ence=FAILURE }\end{array}$} & \multicolumn{4}{|c|}{$\begin{array}{l}\text { Restricted sample: } \\
\text { High-tech-Firms }\end{array}$} \\
\hline & Coeff. & $\begin{array}{l}\text { Std. } \\
\text { error }\end{array}$ & Coeff. & $\begin{array}{l}\text { Std. } \\
\text { error }\end{array}$ & Coeff. & $\begin{array}{l}\text { Std. } \\
\text { error }\end{array}$ & Coeff. & $\begin{array}{l}\text { Std. } \\
\text { error }\end{array}$ \\
\hline & \multicolumn{2}{|c|}{$\begin{array}{c}\text { failure event 1: } \\
\text { voluntary exit }\end{array}$} & \multicolumn{2}{|c|}{$\begin{array}{c}\text { failure event 2: } \\
\text { bankruptcy }\end{array}$} & \multicolumn{2}{|c|}{$\begin{array}{c}\text { failure event 1: vol- } \\
\text { untary exit }\end{array}$} & \multicolumn{2}{|c|}{$\begin{array}{c}\text { failure event 2: } \\
\text { bankruptcy }\end{array}$} \\
\hline Found. year 2006 & -0.183 & $(0.389)$ & 0.0191 & $(0.450)$ & -0.0419 & $(0.207)$ & 0.512 & $(0.395)$ \\
\hline Found. year 2007 & 0.169 & $(0.390)$ & 0.228 & $(0.448)$ & -0.0226 & $(0.213)$ & 0.276 & $(0.418)$ \\
\hline Found. year 2008 & -0.140 & $(0.458)$ & -0.445 & $(0.597)$ & -0.303 & $(0.285)$ & -0.371 & $(0.519)$ \\
\hline Found. year 2009 & 0.116 & $(0.502)$ & -0.202 & $(0.587)$ & -0.332 & $(0.321)$ & 0.362 & $(0.503)$ \\
\hline Found. year 2010 & -1.142 & $(0.831)$ & $-1.878^{*}$ & (1.125) & $-0.718^{*}$ & $(0.432)$ & -1.106 & $(0.741)$ \\
\hline Found. year 2011 & -14.66 & (804.9) & 0.645 & $(0.885)$ & $-1.810 * *$ & $(0.786)$ & -0.213 & $(0.826)$ \\
\hline Report. year 2007 & -0.441 & $(0.609)$ & 0.505 & $(0.702)$ & 0.331 & $(0.366)$ & 0.109 & $(0.577)$ \\
\hline Report. year 2008 & 0.323 & $(0.461)$ & -0.252 & $(0.634)$ & 0.269 & $(0.286)$ & 0.368 & $(0.457)$ \\
\hline Report. year 2009 & 0.111 & $(0.445)$ & 0.499 & $(0.516)$ & 0.331 & $(0.270)$ & 0.210 & $(0.428)$ \\
\hline Report. year 2010 & - & $(0.450)$ & 0.611 & $(0.516)$ & -0.0848 & $(0.289)$ & 0.639 & $(0.401)$ \\
\hline Constant & 63.60* & $(21.24)$ & 22.37 & (681.3) & $30.26 * * *$ & $(9.912)$ & 7.083 & $\overline{(21.68)}$ \\
\hline Observations & 1,886 & & & & 6,156 & & & \\
\hline LR chi2 (78) & 145.61 & & & & & & & \\
\hline LR chi2 (74) & & & & & $264.79 * *$ & & & \\
\hline
\end{tabular}

